\title{
CEsifo WORKING

\section{The Role of Institutions and Immigrant Networks in Firms' Offshoring Decisions}

Simone Moriconi, Giovanni Peri, Dario Pozzoli 


\section{Impressum:}

CESifo Working Papers

ISSN 2364-1428 (electronic version)

Publisher and distributor: Munich Society for the Promotion of Economic Research - CESifo $\mathrm{GmbH}$

The international platform of Ludwigs-Maximilians University's Center for Economic Studies and the ifo Institute

Poschingerstr. 5, 81679 Munich, Germany

Telephone +49 (o)89 2180-2740, Telefax +49 (o)89 2180-17845, email office@cesifo.de

Editors: Clemens Fuest, Oliver Falck, Jasmin Gröschl

www.cesifo-group.org/wp

An electronic version of the paper may be downloaded

- from the SSRN website: $\quad$ www.SSRN.com

- from the RePEc website: $\quad$ www.RePEc.org

- from the CESifo website: www.CESifo-group.org/wp 


\title{
The Role of Institutions and Immigrant Networks in Firms’ Offshoring Decisions
}

\begin{abstract}
The offshoring of production by multinational firms has expanded dramatically in recent decades, increasing these firms' potential for economic growth and technological transfers across countries. What determines the location of offshore production? How do countries' policies and characteristics affect the firm's decision about where to offshore? Do firms choose specific countries because of their policies or because they know them better? In this paper, we use a very rich dataset on Danish firms to analyze how decisions to offshore production depend on the institutional characteristics of the country and firm-specific bilateral connections. We find that institutions that enhance investor protection and reduce corruption increase the probability that firms offshore there, while those that increase regulation in the labor market decrease such probability. We also show that a firm's probability of offshoring increases with the share of its employees who are immigrants from that country of origin.
\end{abstract}

JEL-Codes: F160, J380, J240.

Keywords: offshoring, product market, labor regulations, networks, fixed start-up costs.

Simone Moriconi

Iéseg School of Management \& LEM

Paris / France

s.moriconi@ieseg.fr

Giovanni Peri

University of California, Davis / USA

gperi@ucdavis.edu
Dario Pozzoli

Copenhagen Business School / Denmark

dp.eco@cbs.dk

October 8, 2018

Funding from the Danish Research Council (grant number: 7024-00007A) is gratefully acknowledged. We would also like to thank participants at the RES 2018 Annual Conference, the CESifo Area Conference on Global Economy and the 2018 Mid-west International Trade Conference for their helpful advice and feedback. We also thank the Tuborg Research Centre for Globalisation and Firms at the Aarhus University School of Business and Social Sciences for granting access to Danish registry data. The registry data build on anonymized micro datasets owned by Statistics Denmark. To enhance the scientific validation of analyses published using DS micro data, the Aarhus University Department of Economics and Business helps researchers obtain access to the data set. The usual disclaimers apply. 


\section{Introduction}

The rapid increase in production offshoring has been a pervasive trend deeply affecting the structure of the production and labor markets of several developed countries in recent decades. The driving forces of firm offshoring have been extensively studied (Bernard and Jensen, 1999). Nevertheless, the factors that shape domestic firm boundaries are debated (Barba Navaretti et al., 2011). Firms' decisions regarding offshore production have been described by heterogeneous firm models of trade, such as the one proposed by Melitz (2003). In these theoretical models, the probability of engaging in offshore production is a negative function of the entry cost that the firm must pay in a destination country in order to start production. The high fixed costs of operating a business (e.g., due to lengthy bureaucratic procedures, inefficient financial institutions, and sluggish labor markets in the destination country) may discourage firms from offshoring production activities in those countries.

Many empirical studies based on firm-level data show that firms engage in trade activities only if their productivity levels are high enough to cover the fixed costs of trade (see Sofronis K. Clerides, 1998; Bernard and Jensen, 1999; and Greenaway and Kneller, 2004, among many others). None of these studies, however, has identified the factors determining firms' fixed costs for offshoring production or measured the impact of these costs on firms' propensity to offshore. Partial exceptions can be identified in the literature on foreign direct investment (FDI). Olney (2013) uses a cross-country database compiled by the OECD to show that US firms have a greater FDI presence in countries with more liberal employment protection legislation. On the other hand, Antras et al. (2009) study how the cross-border activities of global firms relate to institutions that produce different levels of investor protections and capital market development. Their model predicts that arm's length technology transfers are more common than technology transfer through foreign affiliate activity in host countries where investor protections are stronger. Moreover, Antras et al. (2009) show that the share of activity abroad financed by capital flows from multinational parents is decreasing in the quality of investor protections in the host economies.

Our study is closely related to these studies. More generally, we analyze the role of a broad set of institutions and policies in the destination countries in affecting the extensive and the intensive margin of offshoring by Danish firms. In addition to analyzing labor market and investor protection, we also consider indices of corruption, measures of bureaucracy and the weak enforcement of standards during the registration process of new companies. Those institutions affect firms' fixed and operating costs (Djankov et al., 2002). Similarly, lax enforcement, such as difficulties in obtaining or recovering credit, or problems in enforcing contracts may hurt economic activity and reduce returns to investments (Acemoglu et al., 
2005).

In our analysis, we also explore the role of individuals in the offshoring firm who are familiar with the destination country, namely, firm employees who are immigrants from those countries. We estimate whether the presence of these immigrants and the size of the group affects the probability and the scale of offshoring in their countries of origin. The presence of a network of foreign workers from specific countries can help firms gather information and navigate the local bureaucracy and culture to comply with burdensome regulations or to obtain better access to credit. More generally, networks can channel information and help firms reduce asymmetries, uncertainties and set-up costs that arise from venturing abroad (Peri and Requena-Silvente, 2010).

Therefore, this paper has two main goals. First, for a large set of institutional characteristics, we test which ones influence firms' offshoring decisions by affecting the costs of setting up offshore business in the country. In particular, we distinguish institutions and policies that reduce the propensity to offshore from those that create an 'offshoring-friendly' business environment and increase offshoring. Second, we analyze whether firms' networks of immigrant employees reduce the fixed costs and facilitate offshoring activities in the employees' countries of origin. We also test whether the network of immigrants is more or less effective in promoting offshoring in the presence of some of the institutional features analyzed above. To answer these research questions, we use three main datasets. The first is the Doing Business database compiled by the World Bank (see Djankov et al., 2002), which is a crosscountry database with information on regulations in over 160 countries for the 2006-2012 period. This dataset covers business regulations in many different areas ${ }^{1}$. The database also includes information on labor market regulations about hiring practices, hours worked, redundancy rules and minimum wage provisions. The second data source is the Worldwide Governance Indicators (WGI) project for the 2006-2012 period (Kraay, 2010), from which we take a country-year-specific measure for corruption. The third data source is a Danish employer-employee matched dataset that covers the universe of individuals and firms in the manufacturing sector for the same period. This dataset is especially well suited for studying firms' offshoring decisions since it allows international trade transactions to be measured at the firm level (Hummels et al., 2014a) rather than at the country level (Olney, 2013). This dataset also includes extensive information on the characteristics of firms' employees, including their country of birth, so that we can identify the network of immigrant workers in each firm.

\footnotetext{
${ }^{1}$ The areas covered are, specifically, the following: starting a business, registering property rights, obtaining credit, protecting minority investors, paying taxes, trading across borders, enforcing contracts and resolving insolvency.
} 
Our main results suggest that business and labor market regulations have opposing effects on offshoring activities. Business regulations increase the probability (extensive margin) of offshoring. A lack of credit coverage and the inadequate protection of creditors' property rights result in high fixed costs of offshoring. Accordingly, business regulation that enhances credit coverage and resolves insolvency issues in destination countries tend to increase firms' propensity to offshore there. This finding is interesting, as it suggests that regulations ensuring the protection of creditors and property rights increase the probability of investment in a country. This finding is partly contrary to existing negative views about business regulations (see, e.g., Djankov et al., 2002). Conversely, labor market regulations have a negative impact on the propensity to offshore: stringent measures of employment protection increase firms' labor costs, which negatively affect firms' extensive margin of offshoring. This result is in line with the general view that employment protection regulations increase labor market frictions and labor costs. We also find that a lack of control of corruption in the destination country highly decreases firms' probability of offshoring to that destination. Corruption is a tax on offshoring (as bribery is costly) and may increase uncertainty and unreliability in the local environment. Different from the "extensive margin," the "intensive margin" of offshoring, namely, the value of offshore activity conditional on investing, is never significantly affected by the institutional measures that we analyze. This argument is consistent with the hypothesis that regulations, corruption and the network of immigrant workers affect the fixed, rather than the variable, costs of accessing a foreign market. Once the initial cost of setting up production in a country is paid, there is no additional effect on the size of operations. We also find that a firm's network, measured as the share of workers from a foreign country, has a significant positive effect on the extensive margin of offshoring in that country, consistent with its role in reducing fixed costs of offshoring. ${ }^{2}$ Several refinements to the network variable confirm the role played by foreign workers in promoting offshoring activities at the bilateral level. We also find that the positive impact of networks is magnified (attenuated) in destination markets with high levels of credit risk (corruption). In this respect, it appears that a thick network of immigrants can partly compensate for high credit risk, possibly ensuring a level of trust and knowledge that reduces such risk. On the other hand, immigrant workers may warn their firms of the high level of corruption in their own countries so that the negative effect of corruption on offshoring is enhanced for firms with a larger network from those countries.

\footnotetext{
${ }^{2}$ Our findings are different from those in Ottaviano et al. (2018), who find a negative effect of network at the bilateral level. That paper focuses on service trade and emphasizes that imported service tasks can be substituted by immigrants working in the firm. We instead explore the offshoring of production activities for a representative sample of firms in the manufacturing industry, where the information channel may be more important than task substitution.
} 
In the next section, we present a conceptual framework for the fixed costs of offshoring. Our empirical strategy is explained in Section 3. The data and summary statistics are then discussed in Section 4. We present our results in Section 5 and conclude in Section 6. The figures and tables are provided in the Appendix.

\section{Theoretical Intuition}

We consider a multi-country economy, with a continuum of countries $i, j \in[0,1]$. There are two sectors in this economy. One sector provides a single homogeneous good. This good is used as the numeraire, and its price is set at 1. This good is produced under perfect competition. The second sector supplies a differentiated good under monopolistic competition: each firm is a monopoly for the variety of good that it produces, and varieties are imperfect substitutes. All the countries produce both goods, which can be freely traded.

\subsection{Demand}

We assume the world is populated by a unit measure of consumers with identical preferences. The utility function of these consumers is increasing in the consumption of the homogeneous good $x_{o}$ and in the quantity $q(x)$ of each variety $x$ of the differentiated good, where $X$ is the set of all the available varieties:

$$
U=x_{o}^{1-\mu}\left(\int_{x \in X} q(x)^{\frac{\sigma-1}{\sigma}} d i\right)^{\left(\frac{\mu \sigma}{-1+\sigma}\right)} .
$$

$\sigma>1$ is the elasticity of substitution between varieties, $\mu$ is the share of income devoted to consumption of the differentiated good (so $1-\mu$ represents the consumer's expenditures devoted to $x_{o}$ ). Consumers choose the demand for the differentiated good that maximizes their utility (1) subject to their budget constraint. In this typical Dixit-Stiglitz framework, the (inverse) demand function for a single variety is

$$
p(x)=A q(x)^{-\frac{1}{\sigma}}, \quad \text { where } A=\left(\frac{P^{1-\sigma}}{\mu}\right)^{-(1 / \sigma)}
$$

The inverse demand function (2) features an index $A$ of the market size of the differen- 
tiated sector, which is increasing in the price index $P$ :

$$
P=\left(\int_{x \in X} p(x)^{1-\sigma} d x\right)^{1 / 1-\sigma}
$$

\subsection{Offshoring and supply}

Regarding the supply of the differentiated good, in each country, there is a continuum of firms $z$; these firms are heterogeneous in their productivity $\theta_{z} \in[0,1]$ and produce a single variety of the differentiated product. The production technology of firms includes both headquarter tasks, $h$, and manufacturing tasks, $m$. Headquarter services are performed locally and thus identify the home country of the firm. The manufacturing tasks are supplied everywhere and can be performed in different countries, i.e., offshored abroad.

We assume that labor is the only factor of production in the economy. Labor is supplied inelastically in all countries and is used both to produce the homogeneous good and to perform the tasks necessary to produce the differentiated good. Perfect competition in the homogeneous sector and free trade imply that wage rates are set at their reservation level and equalized across countries, so they can be set equal to one.

Let us now consider a firm in country $i$ that offshores production to foreign country $j$. We use the following Cobb-Douglas production function:

$$
x_{i j}(z)=\theta_{z}(h)^{1 / 2}\left(\lambda_{j} m\right)^{1 / 2} .
$$

The output of firm $z$ from country $i$ depends on its productivity, $\theta_{z}{ }^{3}$, the local headquarter's inputs, $h$, and the manufacturing inputs, $m$, which are offshored to country $j . \lambda_{j}>1$ is the efficiency of the labor inputs available in country $j$ in terms of the performance of manufacturing tasks. We assume that $\lambda_{i}=1$, so $\lambda_{j}>1$ implies that firms can access more efficient manufacturing inputs by offshoring production. Finally, note that the production function (4) features technology that is equally intensive for manufacturing and headquarter services.

All firms incur a positive fixed cost $f>1$ when they start production. An additional positive fixed cost, $r_{j}>0$, is paid by firms when they offshore production to country $j$, e.g., due to a different functioning of the institutions there (such as weaker enforcement of judi-

\footnotetext{
${ }^{3}$ As the productivity distribution is country-specific, we should also add subscript $i$. However, for the sake of simplicity, we omit it, and as we focus on country $i$, this does not reduce clarity.
} 
cial institutions, higher regulatory constraints, and higher levels of corruption), information frictions, and linguistic barriers. However, some of these entry costs are attenuated when a firm has a specific network in country $j$ (e.g., created by the firm's workers who originate from country $j$ ), $0<\phi_{z j} \leq 1$. $^{4}$

The profit function of an offshoring firm is

$$
\pi_{i j}(z)=p x_{i j}(z)-(h+m)-\left(f+r_{j}-\phi_{z j}\right)
$$

We now substitute demand (2) and the production function (4) into (5). After some simplifications, we obtain

$$
\pi_{i j}(z)=A\left(\theta_{z}(h)^{1 / 2}\left(\lambda_{j} m\right)^{1 / 2}\right)^{\frac{-1+\sigma}{\sigma}}-(h+m)-\left(f+r_{j}-\phi_{z j}\right) .
$$

The firm chooses $h$ and $m$ to maximize (6). From the first-order conditions, we obtain the input demand for the offshoring firm:

$$
m^{*}(z)=h^{*}(z)=\left(\frac{A}{2}\right)^{\sigma}\left(\frac{\sigma-1}{\sigma}\right)^{\sigma} \lambda_{j}^{\frac{\sigma-1}{2}} \theta_{z}^{\sigma-1}
$$

where $m^{*}=h^{*}$ follows because headquarters and manufacturing services have the same intensity in the production function. If we substitute (7) back into (6), then we obtain the equilibrium profits of the offshoring firm:

$$
\pi_{i j}^{*}(z)=2^{1-\sigma} A^{\sigma}\left(\frac{\sigma-1}{\sigma}\right)^{\sigma}\left(\frac{1}{\sigma-1}\right) \lambda_{j}^{\frac{1}{2}(\sigma-1)} \theta_{z}^{(\sigma-1)}-\left(f+r_{j}-\phi_{z j}\right) .
$$

From the condition $\pi_{i j}^{*}(z)>0$, we derive the productivity threshold faced by firms that offshore production abroad:

$$
\theta>\hat{\theta}_{z j}, \quad \text { where } \quad \hat{\theta}_{z j}=\frac{2 \sigma}{(\sigma-1) A^{\frac{\sigma}{-1+\sigma}} \gamma_{j}^{1 / 2}}\left(\sigma\left(f+r_{j}-\phi_{z j}\right)\right)^{\frac{1}{-1+\sigma}}
$$

Only firms characterized by a productivity level $\theta>\hat{\theta}_{z j}$ that is sufficiently high will find it profitable to offshore production to country $j$. According to $(9), \hat{\theta}_{z j}$ depends on the size of the differentiated good sector $(A)$; therefore, we define the following lemma.

\footnotetext{
${ }^{4}$ The combined assumptions of $f>1, r_{j}>0$ and $0<\phi_{z j} \leq 1$ imply that the network benefits do not completely offset the fixed costs. These assumptions are necessary to guarantee economies of scale for the firms.
} 
Lemma : More firms will offshore production when the size of the differentiated sector increases, i.e., $d \hat{\theta}_{z j} / d A<0$.

When the size of the differentiated sector increases, more firms will be needed to satisfy the increased demand for consumption. Put differently, as $\hat{\theta}_{z j}$ decreases, more firms will find it profitable to offshore production.

According to equation (9), the number of offshoring firms also depends on the efficiency of country $j$ in tasks $m\left(\lambda_{j}\right)$, the internal economies of scale $(f)$, the institutions of the destination country $\left(r_{j}\right)$ and the networks that are available in the destination country $\left(\phi_{z j}\right)$.

We now express the number of offshoring firms relative to all producing firms in the monopolistic sector, which can be considered the "probability" that one firm taken among the producing firms is offshoring, hence the probability (extensive margin) of offshoring. To do this, we compare the offshoring condition (9) with the one that domestic firms in country $i$ have to meet to engage in production locally. If the manufacturing tasks are completed locally, then firms are not exposed to different institutions (i.e., $r_{i}=0$ ). In addition, they are able to maximize local network benefits (i.e., $\phi_{z i}=1$ ). However, these firms can only access labor inputs that have low efficiency (i.e., $\lambda_{i}=1$ ):

$$
\theta>\bar{\theta}_{z i}, \quad \text { where } \quad \bar{\theta}_{z i}=\frac{2 \sigma}{(\sigma-1) A^{\frac{\sigma}{-1+\sigma}}}(\sigma(f-1))^{\frac{1}{-1+\sigma}} .
$$

It easily follows that the number of offshoring firms relative to non-offshoring firms is an increasing function of the following ratio of thresholds:

$$
\Theta^{o f f}=\frac{\bar{\theta}_{z i}}{\hat{\theta}_{z j}}=\left(\frac{f-1}{f+r_{j}-\phi_{z j}}\right)^{1 /(\sigma-1)} \lambda_{j}^{1 / 2} .
$$

From (11), we obtain three theoretical predictions that provide the basis for our empirical strategy:

Proposition 1: The number of offshoring firms in country $j$ (or equivalently the probability of offshoring in country $j$ ) decreases when institutional fixed costs in $j$ increase, i.e., $d \Theta^{o f f} / d r_{j}<0$.

Proposition 2: The number of offshoring firms in country $j$ increases when the size of the network from that country increases, i.e., $d \Theta^{\text {off }} / d \phi_{z j}>0$. 
Proposition 3: The number of offshoring firms in country $j$ increases when the efficiency of performing the $m$ tasks in country $j$ increases, i.e., $d \Theta^{\text {off }} / d \lambda_{j}>0$.

These propositions simply formalize the intuitions of this simple theoretical framework, and they will guide the empirical analysis on the effects of institutions and networks on firms' offshoring decisions performed next

\section{Empirical Strategy}

The propositions above provide the theoretical micro-foundation for our empirical analysis. We construct an empirical specification in which differences in the fixed costs associated with institutions in the destination country $j$ and variation of the firm $i$ 's networks in country $j$ affect firm $i$ 's offshoring decisions in country $j$. Our baseline specification is the following bilateral regression equation:

$$
O f f_{i j m c t}=\alpha+r_{j t-1}^{\prime} \beta+\gamma \phi_{i j t-1}+X_{i t-1}^{\prime} \zeta+\theta_{i}+\theta_{j}+\theta_{m t}+\theta_{c}+\epsilon_{i j t}
$$

where $O f f_{i j m c t}$ measures either the extensive margin of offshoring (i.e., the presence of offshore production in country $j$ ) or the intensive margin of offshoring (i.e., the value of offshoring activities in country $j$ conditional on offshoring) of firm $i$ in manufacturing industry $m$ localized in municipality $c$ at time $t$. As we clarify later in the data section, the detailed Danish custom data allow us to measure offshoring as the purchases of inputs within the same industry classification as that of the firm's output.

The first set of explanatory variables in equation (12) is the vector $r_{j t-1}$, which includes the institutional features of the country that affect fixed costs of offshoring, such as labor, business, credit regulations and corruption in destination country $j$ and year $t-1$ (see the data section below for a detailed description of these institutional costs). Changes in national regulations and corruption levels will produce changes in costs of offshoring, which are exogenous to the firm and vary across destination countries. Inefficient and risky institutional settings that prevent the enforcement of contracts and jeopardize property rights or limit competition may increase the cost of doing business in a country. We use changes in these policies in a country (e.g., Viscusi et al., 2005) and track their effect on the firm's offshore investments. These changes can reasonably be considered as exogenous from the perspective of a single enterprise, as Danish firms have a very limited influence on the outcome of reform processes outside of Denmark. A potential threat to this identification strategy is that shocks originating with Danish firms could affect the markets and the regulatory frameworks 
of their foreign suppliers or foreign customers. These shocks could be an issue for a large country, such as the United States, but Denmark is a small country of less than six million people and represents a small share of trade, both in the aggregate and for individual partners and products (Hummels et al., 2014a). It is important to note that all the variables included in the vector $r_{j t-1}$ are lagged one period to account for the fact that companies cannot immediately adjust offshoring activities in response to changes in destination markets' institutions.

Equation (12) also includes the explanatory variable $\phi_{i j t-1}$, which proxies for the strength of firm $i$ 's immigrant networks in country $j$. This variable is computed as the firm's share of foreign workers that were born in country $j$ and are employed at time $t-1$. Unobserved firm-specific shocks could influence both the hiring of foreign workers and offshoring. Firms that intend to offshore to a destination country may intentionally hire foreign workers from that country. It may be argued this is an obvious source of endogeneity, which introduces a spurious positive bias in our network coefficient. We therefore pursue a (simple) instrumental variable approach that reduces this endogeneity issue. Specifically, the instrument is the predicted share of foreign workers from country $j$ in municipality $c$, where the firm is located at time $t-1$ with its lagged value as of 1996, i.e., ten years before our sample starts.

$$
\phi_{j c t-1}^{I V}=\frac{F_{j t-1} *\left(F_{j c 96} / F_{j 96}\right)}{P_{c 96}}
$$

where $F_{j t-1}$ is the national stock of immigrants from country $j$ in period $t-1$. These immigrants are allocated to municipality $c$ based on the share of migrants from the same country $j$ in year 1996 (i.e., $F_{j c 96} / F_{j 96}$ ). This approach assumes that new immigrants migrate to cities based mainly on family and friend networks rather than changing local economic conditions, which could be endogenous. By construction, the instrument relies on the predetermined distribution of immigrants across municipalities in 1996 and the subsequent tendency of new migrants to reside in migrant enclaves. This product is then normalized by total employment in the municipality $c$ in $1996\left(P_{c 96}\right)$ to generate a predicted network variable at the municipality-year level. ${ }^{5}$ Figure 1 plots the bilateral share of foreign workers in a municipality against its instrument. A significant positive relationship shows that the instrument is a good predictor of the bilateral share of foreign workers in the firm. This figure offers a visual inspection of the first-stage IVcoefficients that are discussed later in the section (5).

\section{[Insert Figure 1 about here]}

\footnotetext{
${ }^{5}$ See Card (2005) for additional details on the shift-share approach.
} 
It is possible that the distribution of migrant workers across local labor markets in the base year reflects endogenous economic factors that are persistent over time. We test for this potential violation of our exclusion restriction in Table 1. Specifically, we correlate the changes of our bilateral (municipality by country of offshoring) instrument with the presample (2000-2005) trends in the destination-specific offshoring outcomes. The instrument predicts the change in immigrants by country of origin and municipality from 2006 to 2012 , and the first two columns of the Table show that these are unrelated to the pre-2000 trend of the extensive margin of offshoring (column 1) or the pre-2000 trend of the intensive margin of offshoring (column 2). At the same time, column 3 shows that our bilateral instrument is a strong predictor of the change in immigrants from 2006 to 2012 at the municipality level, confirming that it is a strong instrument even after controlling for municipality fixed effects.

[Insert Table 1 about here]

Equation (12) allows us to test Propositions 1 and 2. The test of Proposition 1 on the effect of institutional fixed costs on firms' offshoring can be summarized by the following hypothesis:

Hypothesis 1: $\beta<(=) 0$ for the extensive (intensive) margin of offshoring. The coefficient $\beta$ measures the bilateral impact of an increase in the fixed costs associated with the institutional feature $r$ on the decision of firm $i$ to offshore in country $j$. This coefficient is predicted to be negative (zero), as the extensive (intensive) margin of the offshoring is assumed to be negatively related to (independent from) an increase in the fixed cost of offshoring.

This prediction implies a negative effect of institutionally driven fixed costs on the extensive margin of offshoring. Proposition 1 is in fact derived from a Melitz-type theoretical framework, similar to the one presented above, in which the fixed costs affect the firms' decisions to offshore production tasks and not the firms' offshoring volumes (conditional on offshoring).

The empirical test of Proposition 2, on the effects of networks on firms' offshoring, can be summarized by the following hypothesis:

Hypothesis 2: $\gamma>(=)$, for the extensive (intensive) margin of offshoring. The coefficient $\gamma$ measures the impact of the size of the immigrant network between firm $i$ and country $j$. A larger presence of immigrants can help firm $i$ decrease the total fixed costs of offshoring 
in these immigrants' country of origin. This coefficient is predicted to be positive (zero), as the extensive (intensive) margin of offshoring is positively related to (independent from) a decrease in the fixed cost brought by a larger network.

This prediction states that a strong bilateral network of immigrants working in firm $i$ and originally from country $j$ is expected to facilitate its cross-border transactions with $j$ by reducing all the fixed costs of setting up an off-shore relation. This assumption is consistent with the notion that foreign workers increase the knowledge and the trust that promote bilateral trade relations by decreasing their fixed costs.

While we focus on the test of Propositions 1 and 2, Proposition 3 regarding the role of firm productivity offers an additional micro-foundation for our empirical specification. According to that proposition, the vector of firm-level controls $X_{i t-1}$ should include proxies of firm productivity. In fact, we include the following variables as controls: value added per worker, capital intensity, foreign ownership, the number of offshoring destinations and size. We also include workforce characteristics among the controls, including employees' average education level, age, tenure and work experience. Moreover, the detailed nature of our dataset allows us to include a comprehensive set of fixed effects, including firm fixed effects, $\theta_{i}$, industry by year fixed effects, $\theta_{m t}$, destination fixed effects, $\theta_{j}$, and municipality fixed effects, $\theta_{c}$. These effects will absorb unobserved characteristics of each firm, and industryspecific and country-specific trends that may both be correlated with off-shoring probability and the size of the firm's immigrant network. The standard errors are clustered at the destination-municipality-year level to allow for correlation in the residuals across firms within each municipality-destination-year group.

\section{Data}

As mentioned in the introduction, a novelty of our paper is that we combine three different data sources. The first is Doing Business, a cross-country database that provides information on approximately 160 countries over the 2006-2012 period. This dataset, developed by the World Bank, follows the methodology proposed by Djankov et al. (2002) and is constantly updated and expanded. It covers business and credit regulations for each country in the following areas: starting a business, registering property rights, paying taxes, trading across borders, obtaining credit, and protecting minority investors. This database also measures

labor market regulations on hiring practices, hours worked, redundancy rules and minimum 
wage provisions. ${ }^{6}$ The second dataset includes information on a country-specific measure of corruption, which is obtained from the WGI project (Kraay, 2010). This measure is based on the inverse of the estimated governance component related to the "control of corruption", i.e., a higher indicator in our dataset corresponds to higher levels of perceived corruption. ${ }^{7}$

The third dataset combines the following three main registers on firms and their employees, which are collected by the official Danish statistical institute (Danmarks Statistik): the "Integrated Database for Labor Market Research" (IDA), the "Accounting Statistics Register" (FirmStat), and the "Foreign Trade Statistics Register" (Udenrigshandelsstatistikken).

The IDA is a longitudinal employer-employee register that compiles information on the age, gender, nationality, education, occupation, and wages of individuals aged 15-74 between 1980 and 2012. The information is updated once a year in week 48. Apart from deaths and permanent migrations, there is no attrition in the data. The individual information in $I D A$ is used to measure detailed workforce composition characteristics at the firm level, as explained in the next section. This information includes the share of foreign workers from each destination country $j$, the share of male employees, and the workers' average age, education level and work experience. Because we can track people over time, we can also establish the average tenure of all employees since 1980.

FirmStat is a firm register that provides the annual value of capital stock, the productivity and the industry affiliation of firms over the 1995-2012 period. ${ }^{8}$ These data capture some of the salient firm-level characteristics included in all of our regression models, which are described in the next section.

The "Foreign Trade Statistics Register" includes import purchases (and export sales) and the number of imported (exported) products at the firm level over the 1995-2012 period. These data are available both for specific destinations and aggregated over all destinations. Import (and export) volumes are recorded in the Danish kroner (DKK) according to the

\footnotetext{
${ }^{6}$ Recent updates to this dataset include information on business regulations on the provision of electricity, construction permits and labor market regulations on severance payments. However, we do not consider these regulations in this analysis because they are available for a large group of countries only from 2014 on.

${ }^{7}$ The original Control of Corruption (CC) indicator captures perceptions of the extent to which public power is exercised for private gain, including both petty and grand forms of corruption, as well as the "abduction" of the state by elites and private interests. We use the inverse of this estimated governance indicator in standard normal units, ranging approximately from -2.5 (low levels of perceived corruption) to 2.5 (high levels of perceived corruption).

${ }^{8}$ Capital stock includes the sum of the value (in the Danish kroner) of land, buildings, machines, equipment and inventory. Firm productivity, which is the most important predictor of firms' internationalization in recent trade theory, is calculated as revenues per employee in logarithmic scale (i.e., labor productivity). We deflate all the monetary values using the World Bank's GDP deflator, with 2005 as the base year. Approximately 16 percent of the firms in the final sample have imputed accountings. Excluding these observations from the main sample provides almost identical results to those reported in the paper. These additional results are available on request from the authors.
} 
8-digit combined nomenclature as long as the transaction is worth at least 7,500 DKK or involves goods whose weight is at least $1,000 \mathrm{~kg} .{ }^{9}$

From the population of all firms, we retain only manufacturing firms with at least 10 employees. Thus, we obtain an unbalanced panel of approximately 2,000 firms over the 2006 - 2012 period. Regardless of its offshoring status, each firm is assigned to all 160 destinations, for which the Doing Business dataset is not missing any information on business or labor market regulations.

Using data from the Foreign Trade Statistics Register, we construct a firm-level measure of offshoring. Following Hummels et al. (2014b), we use a "narrow offshoring" measure that is constructed as the sum of imports for the same product category as firm exports and domestic sales. ${ }^{10}$ This narrow measure of offshoring rules out the imports of raw materials that are inconsistent with standard definitions of offshoring. ${ }^{11}$ We examine two aspects of offshoring. First, we analyze whether regulations and networks affect the probability that a firm offshores production activities in a destination market (i.e., the extensive margin of offshoring). Second, we also estimate the impact of institutions and networks on firms' values of bilateral offshoring, conditional on firms already offshoring in the destination market (i.e., the intensive margin of offshoring).

Figure 2 presents the distribution of offshoring across manufacturing industries in Denmark. We report the twelve industries with the highest share of offshoring firms. Offshoring is common in motor vehicles, machinery and equipment, basic metals and textiles, where more than 30 percent of firms offshore.

\section{[Insert Figure 2 about here]}

The most popular offshoring destinations over the 2006-2012 period are reported in Figure 3. Most of the closest countries are included among the top 12 destinations of Danish offshoring. About 60 percent of Danish offshoring takes place within the European Union. Norway, Germany and Sweden represent the top three destinations. These patterns are consistent with the well-known fact that most offshoring takes place among developed countries. Several Eastern European countries are also included in the top 20 countries where Danish firms offshore. Poland, Latvia, Lithuania and the Czech Republic are among the largest recipients of Danish offshoring.

\footnotetext{
${ }^{9} 7,500$ DKK are valued at about 1,000 Euros at the time of writing. Since the introduction of the Euro currency, the Danish Central Bank has adopted a fixed exchange rate policy vis-a-vis the Euro.

${ }^{10}$ The first 6 digits of the Combined Nomenclature in the Foreign Trade Statistics Register are aggregated to the 4-digit level to considerably improve consistency over time.

${ }^{11}$ In the sensitivity analysis, we use an alternative "broad offshoring" measure that includes all the imports of a given firm in a given year, independently of the product code.
} 
[Insert Figure 3 about here]

\subsection{Descriptive statistics}

Table 2 reports the summary statistics of the main variables used in the empirical analysis. According to our destination-specific definition of offshoring, approximately 3 percent of firms conduct offshoring in some foreign country. Focusing on the intensive margin of offshoring, the average value of offshoring to each destination, conditional on offshoring, is approximately 30,000 DKK per firm/year.

[Insert Table 2 about here]

The measure of the immigrants' network variable for firm $i, \phi_{i j t-1}$, is the share of foreign workers from country $j$ at time $t-1$. We also include in our specification the following firmlevel controls: productivity, size, capital intensity, the number of offshoring destinations, and multi-establishment and foreign ownership dummies. We also control for measures of employees' gender, occupation, average age, education, tenure, and work experience. The summary statistics for the networks and control variables are reported at the bottom of Table 1.

Table 3 reports the main descriptive statistics for the measures of institutional/policy quality in the country of potential offshoring. The measures presented are derived from the indicators of labor, business and credit regulations collected by the World Bank at the country level. Specifically, the labor regulations include the following: i) whether fixed-term contracts are prohibited for permanent tasks; ii) the maximum number of working days per week, calculated as 7 minus the maximum allowed number of working days; iii) whether employers must notify or consult a third party before a collective dismissal of employees; and iv) the minimum wage (measured as the ratio of the minimum wage relative to median wages). We combine the labor regulations with a principal component analysis (PCA) to calculate an index that summarizes the intensity of labor market rigidities in a country. The business regulations include the following: i) the time required to start a business (in days); ii) the time required to register property (in days); iii) the time required to prepare and pay taxes (in hours); and iv) the time required to export goods (in days). The corresponding PCA index is also reported in the same table. Finally, the credit-related costs in our empirical analysis include the following: i) the lack of private credit bureau coverage (percent of adults), computed as 100 minus the private credit bureau coverage; ii) the lack of an investors' protection index, calculated as 10 minus the business extent of disclosure 
index (the disclosure index ranges from $0=$ less disclosure to $10=$ more disclosure); iii) the cost of enforcing contracts (percent of claims) ${ }^{12}$ and viii) the rate of insolvency, calculated as 100 minus the recovery rate (cents on the dollar). The PCA index of credit risk is obtained by combining these credit-related items. The last row of Table 2 shows the main descriptive statistics of our country-specific corruption index, which is based on the inverse of the estimated control of corruption indicator (Kraay, 2010). Let us emphasize that all the institutional indexes vary by year for each country, and therefore, the identification in our panel is given by within-country variation over time.

[Insert Table 3 about here]

Figure 4 shows the measures of regulations and corruption, described in Table 3, across different countries in 2006 and in 2012. The charts plot the index in a country in 2006 against the same index in 2012. A few items are worth noting. First, there is non-trivial time-series variation in each index, as the majority of destination countries show deviations from the 45degree line. This variation is the temporal variation we will exploit in our empirical analysis. Second, whereas most of the destination countries have experienced a reduction in business regulations and credit risk over the sample period, the trends for the index of labor market rigidity and our measure of corruption are less clear, as there appear to be equal movements up and down for that index across countries.

\section{[Insert Figure 4 about here]}

Figure 5 shows the destination countries with the highest index along each of the four dimensions described in Table 3. The chart already suggests a degree of correlation across the indexes of business regulation, credit risk and corruption. Five of the destinations with the highest index of business regulations (Angola, Chad, Haiti, Iraq, Ukraine and Venezuela) are also among the countries with the highest credit risk scores, as reported in the two second and third panels, respectively. Furthermore, the second and fourth panels of Figure 5 reveal that the 5 destinations with the highest corruption index are also among the countries featuring the highest credit risk. We do not observe the same correlation in the country ranking in terms of labor market rigidity and the other three rankings. This result is confirmed by the fact that there is a relatively low and negative correlation between the index of labor market

\footnotetext{
${ }^{12}$ The cost is recorded as a percentage of the claim, which is assumed to be equivalent to 200 percent of income per capita or 5,000 dollars, whichever is greater. Three types of costs are recorded: court costs, enforcement costs and average attorney fees.
} 
rigidity and the other three indexes, whereas the index of business regulation is highly and positively correlated with the index of credit risk and the corruption index. ${ }^{13}$

[Insert Figure 5 about here]

Figure 6 shows separate scatter plots of our indexes of labor market rigidity, business regulations, credit risk, corruption and networks against the extensive margin of offshoring aggregated at the destination-year level. A statistically significant negative (positive) relationship is evident between the indexes (the size of network) and the average share of firms that offshore at the year-destination level. Consistent with our hypothesis, the number of offshoring firms decreases (increases) when the institutional fixed costs (size of networks) increase. These significant relationships are consistent with our main propositions and are already present in the simple data. Next, we examine whether these results hold in a more rigorous empirical specification. Then, Figure 7 plots the indexes and networks measure against the average log of offshoring values at the year-destination level. The intensive margin of offshoring, instead, does not correlate with either the institutional indexes or with the size of the network.

[Insert Figures 6 and 7 about here]

\section{Results}

Our main estimates are obtained from equation (12), and we focus on the coefficient of the institutional and network variables. We then investigate how institutions and networks interact with each other, and finally, we show extensions, checks and refinements of the main results.

\subsection{Main results}

Table 4 presents the baseline results showing the impact of regulations and networks on the extensive margin of offshoring. In column 1, we report a specification controlling for industry only by year, firm and municipality fixed effects. In this specification, we observe that stronger employment protection, weaker credit coverage, a lower resolving-insolvency

\footnotetext{
${ }^{13}$ The correlation coefficient between the index of labor market rigidity and the index of business regulation (index of credit risk) is $-0.22(-0.26)$. The correlation coefficient between the index of business regulation and the index of credit risk (corruption index) is $0.56(0.70)$.
} 
index and higher corruption at time $t-1$ decrease the probability that a firm offshores in that destination at time $t .{ }^{14}$ None of the business regulations are significantly associated with the probability of offshoring. ${ }^{15}$ In contrast, the immigrant network variable is positively associated with the firm's extensive margin. In Columns 2-4, we sequentially add firm-level controls (such as labor productivity) and destination country fixed effects into the specification. Furthermore, the network variable is instrumented by using its shift-share prediction, as described in equation (13). ${ }^{16}$ The coefficients for the institutional indexes remain unchanged after controlling for firm's characteristics and fixed effects. The coefficient estimated on the network variable via IV is of smaller size but still statistically significant. This finding suggests an upward bias of OLS potentially due to the omission of an unobserved variable, which is correlated with the firm's tendency to hire foreign workers and the propensity to offshore in general simultaneously. The same coefficients are never statistically significant when we consider the intensive margin, conditional on the decision to offshore (see Columns $5-8) .^{17}$

We interpret these results as being consistent with our two main hypotheses. On one hand, in line with Hypothesis (1), the presence of restrictive employment protection legislation, high levels of perceived corruption, and the lack of credit coverage and credit solvency proxy for the institutional costs of offshoring in a country and increase fixed costs, reducing the probability of offshoring (i.e., firms' extensive margin). There is no evidence, however, that they affect the volume of offshoring, conditional on entering a specific foreign market. On the other hand, consistent with Hypothesis (2), a firm's immigrant network with the country of destination helps the firm reduce the overall fixed costs (Peri and Requena-Silvente, 2010), which, in turn, positively affects the probability of offshoring but not the offshoring volume. We also find (see last row) a positive association between labor productivity at the firm level and offshoring. This finding is consistent with our theory prediction and with the prediction of any Melitz-type theoretical framework.

\section{[Insert Table 4 about here]}

To simplify the interpretation of our main results, we now present the results obtained

\footnotetext{
${ }^{14}$ To simplify the comparison across coefficients, all the regression tables show standardized coefficients estimated on the z-score of each explanatory variable.

${ }^{15}$ This result may be due to the fact that our credit variables are highly correlated with business regulations. If we estimate a simpler specification in which credit and business regulations are entered separately into the extensive margin equation, we find that they are all significantly and negatively associated with the probability of offshoring.

${ }^{16}$ The first-stage results, which are reported in the bottom panel of Table 4 , show that the instrument has a significant positive impact on our network variable.

${ }^{17}$ Very similar results are obtained by using an alternative measure of the intensive margin, which is calculated as the share of destination-specific imports in total imports.
} 
by using the PCA indexes calculated for each type of regulation. Column 1 of Table 5 includes the coefficients estimated for the index of labor market rigidity, business regulations and credit risk in the most complete specification for the extensive margin. These results are in line with the findings obtained with the disaggregated measures: although business regulations do not affect the extensive margin, an increase in labor market rigidity and credit risk in the destination country significantly reduces the firm's bilateral probability of offshoring. ${ }^{18}$ Quantitatively, our regression analysis suggests that a one-standard-deviation increase in the index of labor market rigidity ${ }^{19}$ at time $t-1$ will lead to a 0.007 decrease in the probability of offshoring, i.e., a 20 percent decrease in the firm's extensive margin of offshoring. ${ }^{20}$ The impact of credit risk is approximately half this amount: the firm's bilateral probability of offshoring is reduced by 10 percent at time $t$ when there is a onestandard-deviation increase in the related index at time $t-1 .^{21}$ Consistent with the results reported in Table 4, our measure of corruption negatively affects the probability of offshoring: a one-standard-deviation increase in the corruption index decreases the extensive margin by approximately 3 percent. ${ }^{22}$ Furthermore, the presence of an immigrant network in the country of destination within the firm at time $t-1$ positively affects the extensive margin. According to the instrumented coefficient, a one-standard-deviation increase in the firm's network leads to a 0.010 increase in the probability of offshoring, which corresponds to an increase of approximately 32 percent in the extensive margin. Notice that the effects estimated for institutional quality on the probability of offshoring are comparable to the impact of productivity: a one-standard-deviation increase in the firm's productivity is in fact associated with only a 3 percent increase in the probability of offshoring.

\footnotetext{
${ }^{18}$ As mentioned in Section 4.1, destinations with high credit risk also tend to have numerous business regulations, which may explain the lack of significance observed for the index of business regulations. In fact, when we add these indexes separately in the main specification, the estimated coefficients are all negative and statistically significant. These additional results are available on request from the authors.

${ }^{19}$ This approximately corresponds to an increase in labor market rigidity from the level of Austria, whose average index is at the median of the distribution, to that of Portugal, whose average index is at the 95th percentile of the distribution.

${ }^{20}$ This figure is calculated by dividing our standardized coefficient by 100 for the average firm's probability of offshoring, as reported at the bottom of Table 5 .

${ }^{21}$ This figure approximately corresponds to an increase in credit risk from the level of Germany, whose average index is at the median of the distribution, to that of Macedonia, whose average index is at the 95th percentile of the distribution.

${ }^{22}$ This approximately corresponds to an increase in the corruption index from the level of France, whose average index is at the 25th percentile of the distribution, to that of Azerbaijan, whose average index is at the 90 th percentile of the distribution.
} 


\subsection{Refinements to the main results: the role of interactions}

An interesting question to ask is whether the institutional indexes interact with the immigrant network variable. This analysis is performed in Table $5{ }^{23}$ The presence of a network of immigrants may play a stronger role in encouraging offshoring in countries where local institutions are bad because the network provides information to reduce investment risk or to increase local knowledge, which is particularly valuable in places with low institutional protection of investments. Consistent with this hypothesis, we find a positive and significant interaction coefficient between the network variable and the credit risk index, which suggests that the positive effect of a network is magnified in destinations characterized by high credit risk. Our finding is consistent with the notion that an immigrant's networks may act as a substitute for institutions that guarantee creditors (i.e., reduce the costs associated with credit risk) and increase the firm's bilateral probability of offshoring to a certain destination. On the other hand, we do not find significant interaction effects between networks and the other two indices. Furthermore, the measure of corruption interacts negatively with the network variable: the positive effect of networks is in fact reduced in destinations characterized by high levels of corruption. Networks are therefore less effective in promoting offshoring in corrupt environments, which may be due to the fact that immigrants, given their insider knowledge, allow a firm to better identify the risk of corruption and to avoid corrupt places. To simplify the interpretation of all these findings, we plot the estimated marginal effect of our network variable on the extensive margin against the whole distribution of the two indexes of credit risk and corruption. Specifically, the top (bottom) panels of Figure 8 report the estimated marginal effects of the immigrant network against the standardized index of credit risk (corruption) by setting the indexes of business regulations, labor market rigidity and corruption (credit risk) at the 25th, 50th and 75th percentiles of the distribution of these indexes, respectively. ${ }^{24}$ These plots confirm the substitutability (complementarity) between

\footnotetext{
${ }^{23}$ The interactions of the regulation indexes with the network variable are instrumented by their interactions with the shift share prediction described in equation (13).

${ }^{24}$ The standard errors of these marginal effects are calculated to account for all the covariance terms involved in the fully interacted specification, as in the following interaction specification:

$$
\begin{array}{r}
\text { Off } f_{i j m t}=\alpha+\gamma_{1} \phi_{i j t-1}+\beta_{1} \text { index_labrig }_{j t-1}+\beta_{2} \text { index_busreg }_{j t-1}+ \\
\beta_{3} \text { index_credrisk }_{j t-1}+\beta_{4} \text { index_corrup }_{j t-1}+\gamma_{2}\left(\phi_{i j t-1}\right)\left(\text { index_labrig }_{j t-1}\right)+\gamma_{3}\left(\phi_{i j t-1}\right) \\
\left(\text { index_busreg }_{j t-1}\right)+\gamma_{4}\left(\phi_{i j t-1}\right)\left(\text { index_credrisk }_{j t-1}\right)+\gamma_{5}\left(\phi_{i j t-1}\right)\left(\text { index_corrup }_{j t-1}\right)+X_{i t-1}^{\prime} \zeta+\theta_{i}+\lambda_{j}+ \\
\eta_{m}+\rho_{t}+\epsilon_{i j t}
\end{array}
$$
}

The marginal effects of the immigrant network variable $\phi_{i j t-1}$ reported in the top panels of Figure 8 are calculated as follows:

$\frac{d O f f_{i j m t}}{d \phi_{i j t-1}}=\gamma_{1}+\gamma_{2}$ index_läbrig $g_{j t-1}+\gamma_{3}$ index_busreg $g_{j t-1}+\gamma_{4}$ index_credrisk $_{j t-1}+\gamma_{5}$ index_corrup $p_{j t-1}$ 
the network variable and the index of credit risk (the corruption index), given that the impact of the former increases (decreases) as the credit risk index (corruption index) in the destination country increases for given levels of the other indexes. The estimated coefficients for our network variable retain their statistical significance along the whole distribution of the two indexes, i.e., credit risk and corruption.

[Insert Figure 8 about here]

Similar results regarding the interaction effects are obtained in a simpler specification, in which we include only the variable for the presence of labor employment protection and a PCA index of credit risk, which is calculated by combining the variables for credit coverage and resolving insolvency (see column 3 of Table 5).

[Insert Table 5 about here]

Consistent with our two main hypothesis, none of the coefficients discussed in Table 5 is precisely estimated in the regression for the intensive margins (columns 4-6). ${ }^{25}$

\subsection{Refinements to the main results: alternate measure of net- works}

Our main analysis used the share of workers in the firm who were born in a foreign country as a measure of the firm's immigrant network in that country. This section examines whether our results hold by using alternative definitions of the immigrant network. Specifically, columns 3 and 4 of Table 6 use the firm's share of white-collar workers (rather than total employment) from each specific country at time $t-1$ as the network variable. Columns 5 and 6 focus on the share of blue-collar foreign workers. For these estimations, we construct

where $i n d e x \_l \bar{a} b r i g_{j t-1}$, index_bussreg $g_{j-1}$ and $i n d e x_{-}$corr $u p_{j t-1}$ are alternatively set at either the 25 th, 50 th or 75 th percentile of the corresponding index distribution. The variance in the marginal effects is calculated by considering the covariance across all the different indexes included in the main specification.

${ }^{25}$ We have also investigated whether there exists a significant interaction between the institution variables. Namely, we have analyzed whether the presence of rigidities/imperfections in one dimension is magnified by the presence of rigidities in another dimension. The individual effects estimated in this specification are consistent with the findings reported in column 1, and none of the interactions is significant at standard levels. These results, which are available on request from the authors, suggest that the linear specification is reasonably good for our institutional variables and that each factor affects offshoring independently from the other. 
analogous instruments using the predicted immigration of white- and blue-collar workers in the municipality in which the firm is located at time $t-1$. The results obtained by using these two narrower definitions of networks are qualitatively similar to the main results reported in columns 1 and 2 for comparison purposes. The size of networks significantly affect the extensive margin of offshoring but not its intensive margin. In terms of the magnitudes of these coefficients, the positive effect of the network provided by white-collar workers is larger than that reported for the blue-collar workers. Specifically, a one-standard-deviation increase in the share of white-collar foreign workers from a specific country doubles the probability of offshoring in that country, whereas the same effect estimated for the blue-collar foreign share is an increase of only 15 percent. These estimates suggest that foreign workers in white-collar occupations (managers, middle managers and professionals) bring with them destination-specific knowledge that can promote offshoring activities in their country of origin more effectively than their blue-collar counterparts. Similarly, in columns 7 and 8 of Table 6 , we estimate the impact of hiring managers from domestic companies that offshore to a specific destination country. Our results show that domestic firms that hire managers with destination-specific offshoring experience are 14 percent more likely to offshore to the same destination country at time $t$. However, conditional on offshoring, they do not offshore larger values. This "poaching" effect on offshoring is consistent with the findings reported in Mion et al. (2017), according to which export experience gained by managers in previous firms improves the export performance of these managers' current firm. All these results combined together reveal that workers with destination-specific knowledge acquired either in their country of origin or in previous companies help domestic firms reduce the fixed costs of offshoring to a specific destination country, especially if they are in a white-collar occupation.

Our main results on the network variable are also confirmed when we use the base-year method to address the endogeneity of the network variable instead of relying on the shiftshare instrumental variable approach. In columns 8 and 9 , our network variable is simply measured as the firm-level share of foreign workers from each country in the base-year. This value is predetermined with respect to the current offshoring decision. The base year is generally set at 2005, i.e., one year before the beginning of the estimation sample. If a firm enters the market and imports at any time during our sample period, we treat its first year of existence as the pre-sample year and focus our estimation on the subsequent changes in offshoring. The results obtained from this alternative approach confirm the main results i.e., larger immigrant networks increase the probability of offshoring in the immigrants' countries of origin, but they do not affect the offshoring volume. The size of the coefficient estimated on the extensive margin is twice as large as that obtained in the main analysis: a one- 
standard-deviation increase in the base year share of foreign workers increases the current bilateral probability of offshoring by 60 percent.

Finally, columns 11 and 12 of Table 6 focus on the bilateral share of foreign workers in the municipality in which the firm is located at time $t-1$ rather than the number of foreign workers in the firm. The instrument is still the shift-share prediction at the municipality level. This specification emphasizes the fact that immigrants in the municipality can be a channel for information, even if they do not work in the firm, by promoting the development of informal networks with foreign workers employed in other companies in the local labor market and indirectly with their countries of origin. The results obtained with this broader measure of networks are almost identical to the baseline results: a one-standard-deviation increase in the bilateral share of foreign workers within the municipality at year $t-1$ increases the extensive margin by 33 percent, and the corresponding effect on the intensive margin is not statistically different from 0 . Ultimately, the results in Table 6 demonstrate that our findings on the network effects are robust to a variety of alternative definitions.

[Insert Table 6 about here]

\subsection{Additional sensitivity analysis}

In this section, we evaluate how the coefficients estimated for the institution and network variables change when we focus on specific sub-samples of firms. We also evaluate how sensitive the results are to alternative specifications of the index measuring institutions. To simplify the presentation of these sensitivity exercises, we discuss only the results obtained from the specification used in columns 1 and 5 of Table 5, i.e., the one featuring the PCA institutional indexes (capturing labor market rigidity, business regulations, credit risk and corruption) and the network variable.

\subsubsection{Non-linear specifications}

Our model predicts that lower costs associated with institutional features of credit, business and labor markets (and stronger networks) in a foreign country are positively associated with the firms' extensive margin of offshoring. The exact form of this positive association is unclear, however. To explore the existence of non-linearities in the effects discussed so far, we consider an additional specification in which we add the squares of the institutional indexes and of the network variable. The results are reported in the first two columns 
Table 7. Our main results are confirmed: in all specifications, higher levels of labor market rigidity, credit risk and corruption in the destination market negatively influence the firm's bilateral probability of offshoring, whereas stronger networks are positively related to this probability. We estimate a convex (concave) relationship for the labor rigidity and the credit risk indexes (the immigrant network). We also find suggestive evidence in support of a concave relationship between the extensive margin of offshoring and the corruption index. As shown in the main specification, the results for the intensive margin reported in the second column of the same table confirm that offshoring volumes are not affected by either networks or institutions, conditional on offshoring.

\subsubsection{Export outcomes}

Because some, but not all, of the determinants of offshoring costs may also affect the costs of exporting to a country, we now explore whether our institutional indexes and immigrant network variable affect firms' export behavior. Even in this case, we distinguish between extensive and intensive margins of exporting. The results are reported in the last two columns of Table 7 and suggest that the firm's probability of exporting to a specific destination market and its export volumes are not affected by the level of labor market rigidity in the destination country; however, they are negatively influenced by the level of credit risk and corruption. Consistent with our expectations, when shifting the focus from offshoring to firms' export decisions, the destination country's credit risk still matters (as credit risk may influence the relation between the exporter and buyers), while the destination country's labor market institutions do not affect exports (because labor costs and rigidities should not affect the behavior of buyers of exported goods). Corruption negatively affects both the extensive and intensive margin of exporting, whereas business regulations are not relevant for export decisions. Furthermore, our network variable positively affects the extensive margin of exporting. This last finding is consistent with the previous trade literature that documents the importance of immigrants' ability to promote trade (Gould, 1994; Head and Ries, 1998; Rauch and Trindade, 2002; Briant et al., 2014; Peri and Requena-Silvente, 2010). Overall, immigrant networks are important for offshoring and exports and therefore serve to reduce credit risks.Labor market institutions, instead, affect only offshoring decisions, as labor is an important input of imported offshore goods but does not play a direct role in exports.

[Insert Table 7 about here] 


\subsubsection{Industry-specific results}

As the large increase in offshoring has been driven by firms' goal of cutting labor costs, we test whether offshoring decisions are more sensitive to the country-specific characteristics analyzed above in sectors where labor is a larger share of total costs (i.e., labor-intensive sectors). The first four columns of Table 8 report the response of offshoring to institutional factors for labor- and capital-intensive industries separately. Here, labor- (capital-) intensive industries are defined as those with an average capital intensity below (above) the mean in the midpoint of our sample (i.e., 2009). This definition is used to investigate whether offshoring firms in labor-intensive industries tend to react more strongly to changes in destination countries' institutional costs or networks. As expected, we find that for firms in laborintensive industries, the probability of offshore is more responsive to the destination country's labor market rigidity than it is for firms in capital-intensive industries. Firms in laborintensive industries also seem to be more reactive to changes in credit risk than firms in other industries. The point estimates imply that a one-standard-deviation increase in labor market rigidity in a destination country leads to a 48-percent decrease in the probability of offshoring in that country for labor-intensive firms, whereas a one-standard-deviation increase in credit risk decreases the same probability by half as much. The effects on the extensive margin for capital-intensive firms are much smaller, a 2.5 percent decrease and an approximately 3 percent decrease, respectively. The coefficient estimated for the business regulations index is never statistically significant, and the magnitudes involved in the corruption and network variables are comparable across the two groups of industries.

The sample we used for the baseline estimates included only pure manufacturing firms because our measure of offshoring (using imported inputs) may be not entirely relevant if applied to the service industry (Hummels et al., 2014b). However, former manufacturing firms may offshore all of their production activities and keep only service-oriented tasks in Denmark. These "factory-less goods producing" firms (FGPFs) are companies that no longer directly control the production and assembly of goods in-house but are still involved in design, R\&D, engineering, supervision of third-party production, branding, marketing and distribution (Bernard and Fort, 2015). The number of firms switching from manufacturing to service industries is non-negligible and can explain approximately half of the recent decline in Danish manufacturing employment (Bernard et al., 2017). This type of extreme offshoring acts as an incentive to check whether the results are similar if estimated for a sample of service firms. In line with the main analysis performed for the manufacturing sector, for service firms, we find that the estimated coefficients for our index of labor market rigidity, credit risk and corruption are negative and statistically significant for the extensive margin of offshoring, as 
reported in the last two columns of Table 8. In addition, the results for business regulations, the network variable and its interaction with institutions are consistent with those obtained for the sample of manufacturing firms. This result suggests that performing the analysis on firms in the service industry does not change the conclusions of the main analysis.

[Insert Table 8 about here]

\subsubsection{Sample-specific results}

It may be argued that the imports of non-exporting firms are less likely to feature actual offshoring activities relative to exporting firms' imports. To check whether our measure of offshoring is somehow weakened by the presence of non-exporting firms, in Table 9, we reestimate our main regression by excluding these firms from the sample. The results obtained from this refinement confirm that the estimated coefficient on all of our variables of interest are qualitatively very similar to the ones estimated in the main analysis.

Another concern is that our sample of destination countries is very heterogeneous, e.g., in terms of the enforcement capabilities of their political institutions (Acemoglu et al., 2005). Therefore, the response of offshoring to institutional costs or networks may not not be homogeneous across macro-geographical groups. To address this concern, we split the sample into developed and developing destination countries. The results obtained from these subsamples are reported in the last four columns of Table 9. It appears that the impact of labor market rigidity, credit risk, corruption and networks on offshoring is indeed stronger for developing destination markets than for developed countries. In the first group, the institutional quality is a more important concern, and variation of this quality may generate a stronger offshoring response. A one-standard-deviation increase in the index of credit risk, for example, triggers a 36 (17) percent increase in the extensive margin of offshoring if we focus on developing (developed) countries as destination markets.

[Insert Table 9 about here]

\subsubsection{Offshoring measures}

We now test the consistency of our results by using alternative measures of offshoring in Table 10. First, in columns 1 and 2, we use a broad offshoring measure, which is defined as the total value of imports by a firm in a given year, regardless of the industry. As discussed in

the data section, this measure is not our preferred measure of offshoring; however, the results 
using this definition of offshoring are similar to our baseline findings, even if the coefficients are higher. For example, a one-standard-deviation increase in credit risk in a country leads to a 20 percent decrease in the probability that a firm will offshore there (using the narrow definition of offshoring, the effect was 10 percent), but it does not affect the log of offshoring volumes, conditional on offshoring.

Second, we construct a new measure of offshoring using a completely different dataset compiled by the National Bank of Denmark (Esperian). This dataset includes firm-level information on outward FDI activity. Specifically, this variable identifies countries in which Danish firms have majority-owned foreign affiliates. Using this information, we construct an extensive margin offshoring variable that measures whether a Danish firm has any foreign affiliates abroad. The benefit of using this approach is that it specifically measures the firm's foreign activities. However, this measure does not measure offshoring to foreign arms' length suppliers that are outside the boundaries of the firm. Moreover, the Esperian data do not indicate whether a particular import transaction originates from a controlled affiliate or an uncontrolled third party. We are therefore able to check the validity of our main results only in relation to the extensive margin of offshoring. Finally, the Esperian data are available only for a sub-sample of our data. The third column of Table 10 reports the results using this alternative FDI-based offshoring measure. Consistent with our baseline results, we find that credit risk negatively affects firms' bilateral probability of offshoring, whereas the immigrant network variable has a positive (although marginally significant) effect on the extensive margin. The magnitudes involved are, however, much smaller than those of the baseline results. Furthermore, the coefficients on the index of labor market rigidity and corruption are only marginally significant. The signs of all these coefficients, however, confirm the baseline results.

[Insert Table 10 about here]

\section{Conclusions}

This paper explores how institutions and networks affect firms' offshoring outcomes by using a large and representative sample of manufacturing firms in Denmark over the 2006-2012 period. Our empirical analysis shows that at least two regulatory areas attract offshoring and affect its extensive margin. A lack of credit coverage, poor protection of creditors' property rights and high levels of corruption are strongly associated with a lower probability of offshoring for a firm. Accordingly, regulations of the destination market that reduce credit risks and corruption tend to increase firms' propensity to offshore. Conversely, regulations 
that increase labor market rigidity have a negative impact on firms' offshoring probability in that country, which may be because stringent employment protection measures increase firms' labor costs, and this negatively affects the extensive margin of offshoring. The impact of these regulations on firms' intensive margins, conditional on offshoring, is instead never statistically significant. This result corroborates the hypothesis that institutions affect the fixed costs (rather than the variable costs) of accessing a foreign market. Our results also suggest that a firm's network of foreign workers has an additional fixed-cost-reducing effect that increases that firm's probability of offshoring. Interestingly, we also find that the positive impact of networks on offshoring is magnified (attenuated) in destination markets with high levels of credit risk (corruption). A network of people knowledgeable about the country may substitute for some of the credit-protection institution in that country. It may also act to increase the knowledge of local corruption, further discouraging firms from offshoring in highly corrupt countries. 


\section{References}

Acemoglu, D., Johnson, S., and Robinson, J. A. (2005). Institutions as a Fundamental Cause of Long-Run Growth. In Aghion, P. and Durlauf, S., editors, Handbook of Economic Growth, volume 1 of Handbook of Economic Growth, chapter 6, pages 385-472. Elsevier.

Antras, P., Desai, M. A., and Foley, C. F. (2009). Multinational Firms, FDI Flows, and Imperfect Capital Markets. The Quarterly Journal of Economics, 124(3):1171-1219.

Barba Navaretti, G., Bugamelli, M., Schivardi, F., Altomonte, C., Horgos, D., and Maggioni, D. (2011). The Global Operations of European Firms - The Second EFIGE Policy Report. Number 581 in Blueprints. Bruegel.

Bernard, A. B. and Fort, T. C. (2015). Factoryless Goods Producing Firms. American Economic Review, 105(5):518-23.

Bernard, A. B. and Jensen, J. B. (1999). Exceptional Exporter Performance: Cause, Effect, or Both? Journal of International Economics, 47(1):1 - 25.

Bernard, A. B., Smeets, V., and Warzynski, F. (2017). Rethinking Deindustrialization. Economic Policy, 32(89):5.

Briant, A., Combes, P.-P., and Lafourcade, M. (2014). Product Complexity, Quality of Institutions and the Pro-Trade Effect of Immigrants. Sciences Po publications info:hdl:2441/781v6i5nuc9, Sciences Po.

Card, D. (2005). Is the New Immigration Really so Bad? The Economic Journal, 115(507):F300-F323.

Djankov, S., Porta, R. L., de Silanes, F. L., and Shleifer, A. (2002). The Regulation of Entry. The Quarterly Journal of Economics, 117(1):1-37.

Gould, D. M. (1994). Immigrant Links to the Home Country: Empirical Implications for U.S. Bilateral Trade Flows. The Review of Economics and Statistics, 76(2):302-16.

Greenaway, D. and Kneller, R. (2004). Exporting and Productivity in the United Kingdom. Oxford Review of Economic Policy, 20(3):358-371.

Head, K. and Ries, J. (1998). Immigration and Trade Creation: Econometric Evidence from Canada. Canadian Journal of Economics, 31(1):47-62. 
Hummels, D., Jorgensen, R., Munch, J., and Xiang, C. (2014a). The Wage Effects of Offshoring: Evidence from Danish Matched Worker-Firm Data. American Economic Review, 104(6):1597-1629.

Hummels, D., Jorgensen, R., Munch, J., and Xiang, C. (2014b). The Wage Effects of Offshoring: Evidence from Danish Matched Worker-Firm Data. American Economic Review, 104(6):1597-1629.

Kraay, Aart Kaufmann, D. M. M. (2010). The worldwide governance indicators : methodology and analytical issues. The World Bank.

Melitz, M. J. (2003). The Impact of Trade on Intra-Industry Reallocations and Aggregate Industry Productivity. Econometrica, 71(6):1695-1725.

Mion, G., Opromolla, L. D., and Sforza, A. (2017). The diffusion of knowledge via managers' mobility. CESifo Working Paper Series No. 6256.

Olney, W. W. (2013). A Race to the Bottom? Employment Protection and Foreign Direct Investment. Journal of International Economics, 91(2):191 - 203.

Ottaviano, G. I., Peri, G., and Wright, G. C. (2018). Immigration, Trade and Productivity in Services: Evidence from U.K. Firms. Journal of International Economics, 112:88 - 108.

Peri, G. and Requena-Silvente, F. (2010). The Trade Creation Effect of Immigrants: Evidence from the Remarkable Case of Spain. Canadian Journal of Economics, 43(4):14331459 .

Rauch, J. E. and Trindade, V. (2002). Ethnic Chinese Networks In International Trade. The Review of Economics and Statistics, 84(1):116-130.

Sofronis K. Clerides, Saul Lach, J. R. T. (1998). Is Learning by Exporting Important? Micro-Dynamic Evidence from Colombia, Mexico, and Morocco. The Quarterly Journal of Economics, 113(3):903-947.

Viscusi, W., Harrington, J. E., and Vernon, J. M. (2005). Economics of Regulation and Antitrust, 4th Edition, volume 1. The MIT Press, 4 edition. 
Figure 1: Bilateral share of foreign workers and its instrument

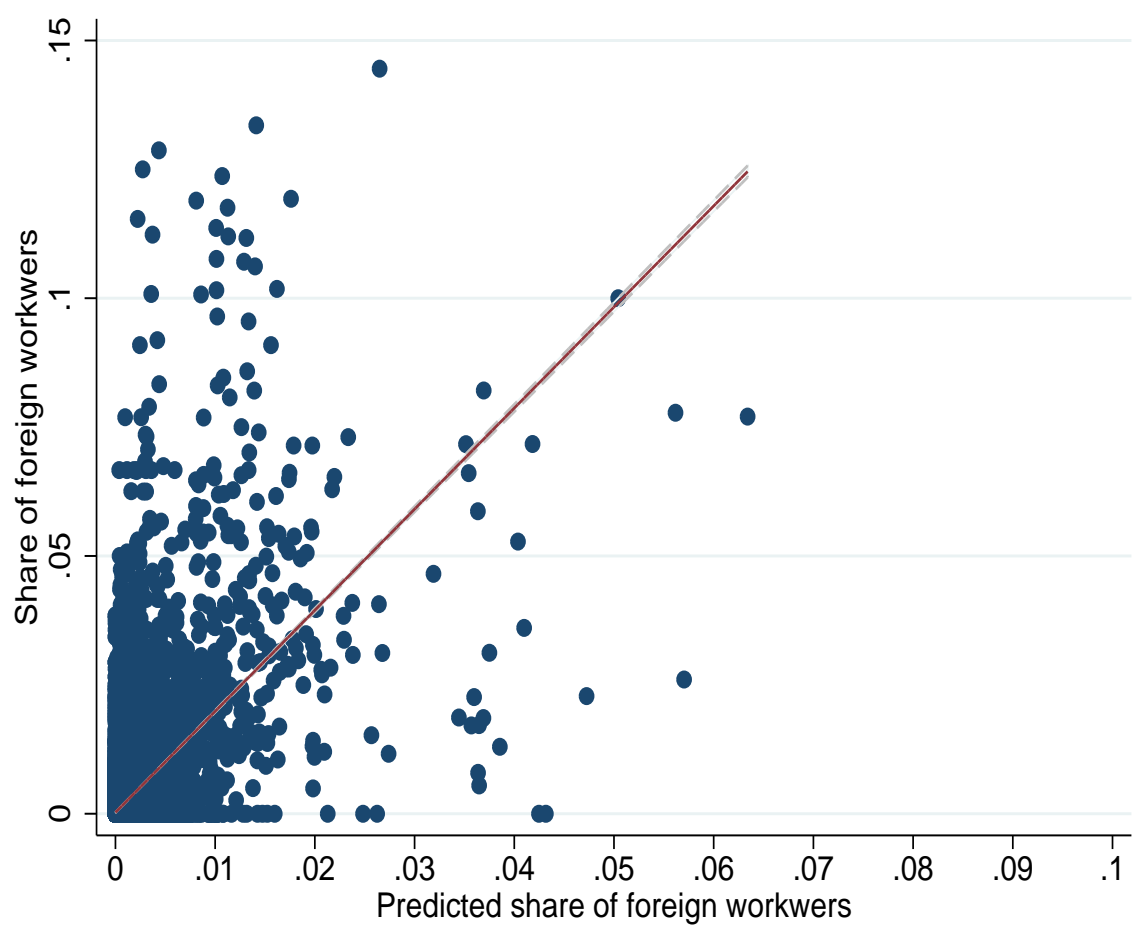

Notes: The bilateral share of foreign workers in a given municipality and year is reported on the vertical axis. The predicted bilateral share (IV) of foreign workers in a given municipality and year is reported on the horizontal axis. 
Figure 2: Sectors with the largest share of offshoring firms on average (2006-2012)

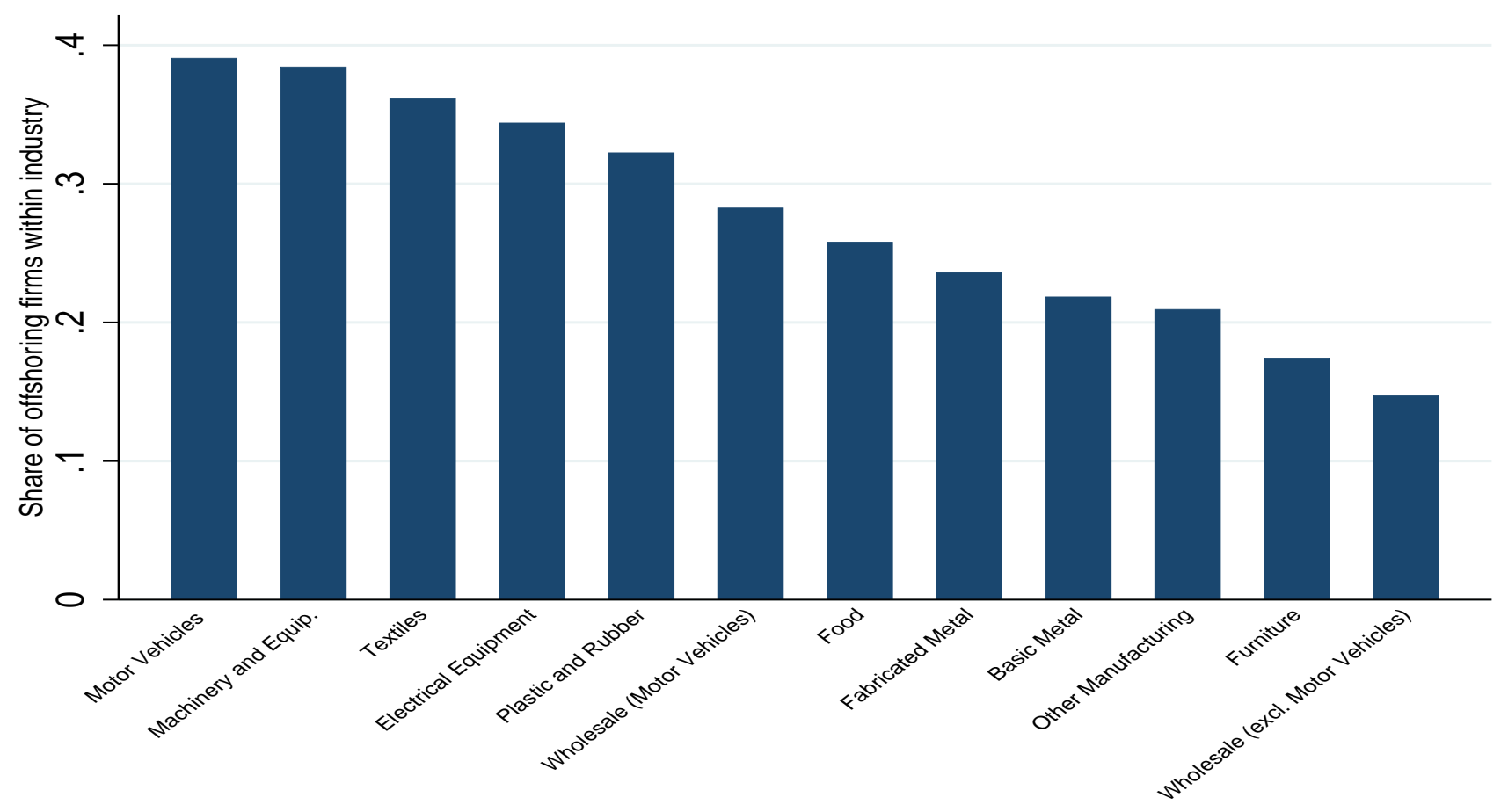

Notes: Authors' calculation using data from the Danish Integrated Database for Labor Market Research. 
Figure 3: Destination countries with the largest share of offshoring firms on average (20062012)

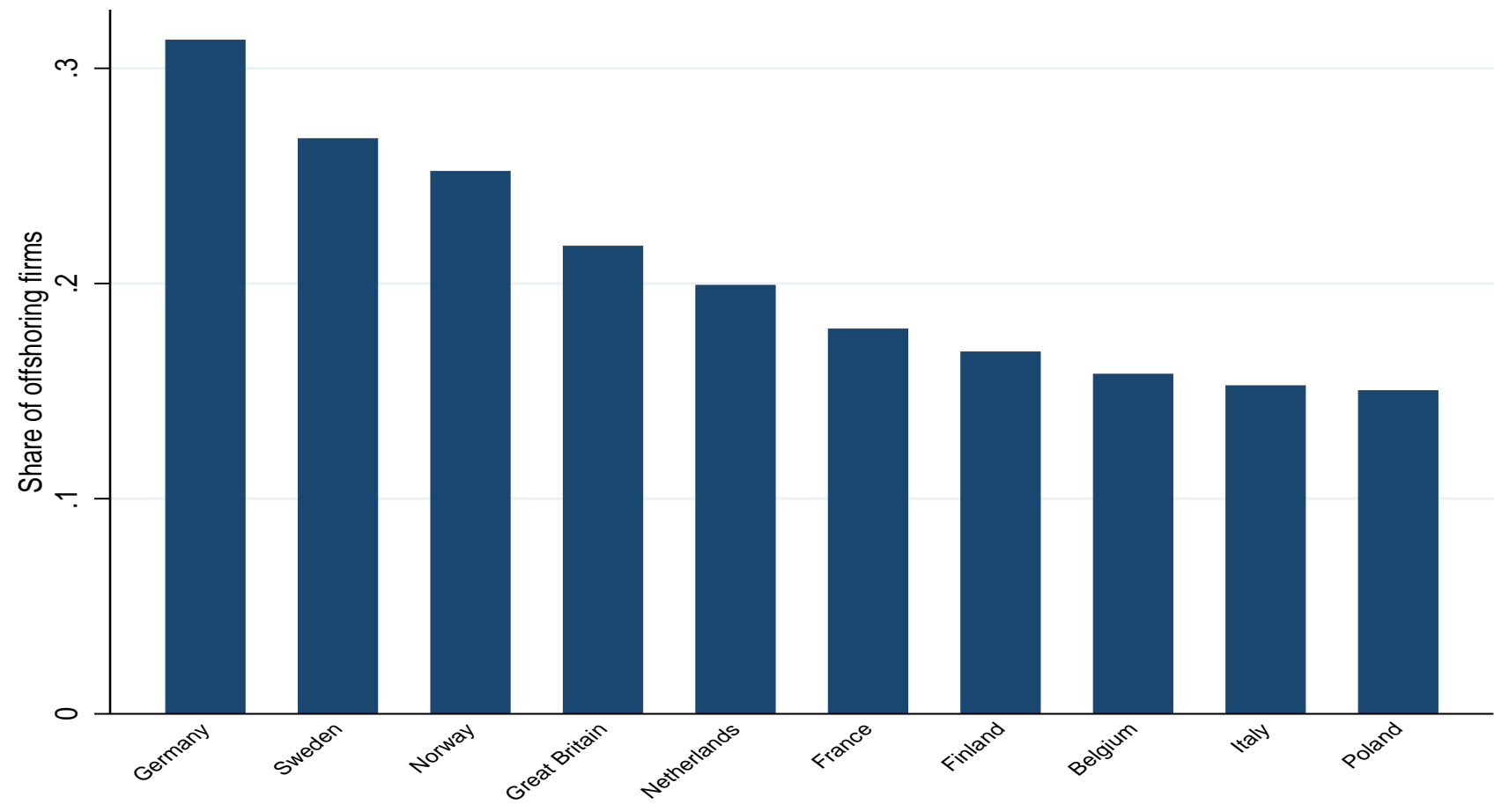

Notes: Authors' calculation using data from the Danish Integrated Database for Labor Market Research. 
Figure 4: Regulations and corruption by destination country in 2006 and 2012
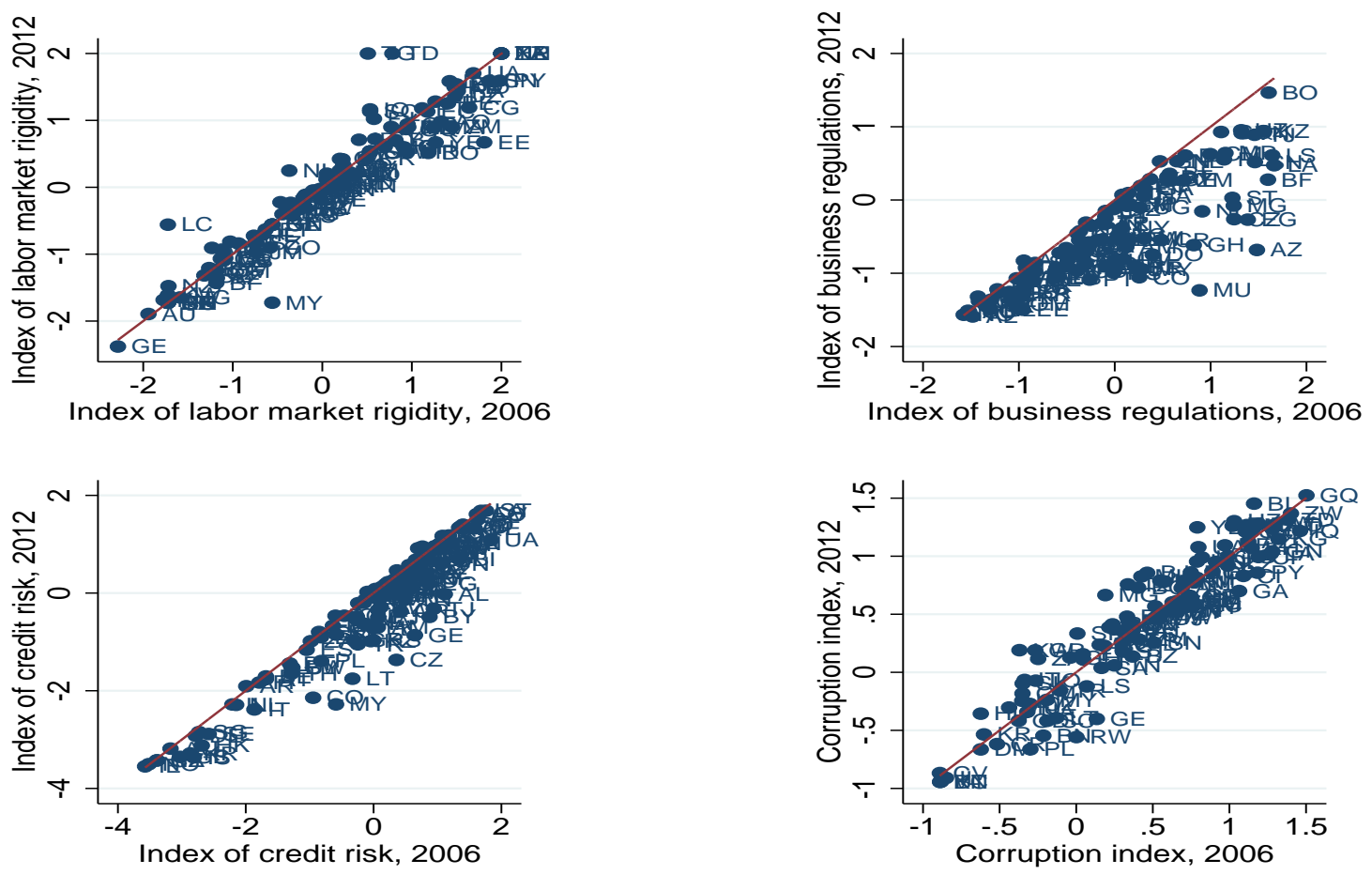

Notes: The index of labor market rigidity is estimated by combining all the labor regulations (limits on fixed term contracts; limits on working days per week; employment protection measures; and the minimum wage) with principal component analysis. The index of business regulations is estimated by combining all the business regulations (the time it takes to open a business; the time it takes to register property; the time it takes to pay taxes; the time it takes to export goods) with a principal component analysis. The index of credit risk is estimated by combining all the credit regulations (100credit coverage; 10-investor protection; enforcing contracts; 100-resolving insolvency) with principal component analysis. The corruption index is the inverse of the estimated control of the corruption indicator. 
Figure 5: Destination countries with the highest regulation and corruption indexes
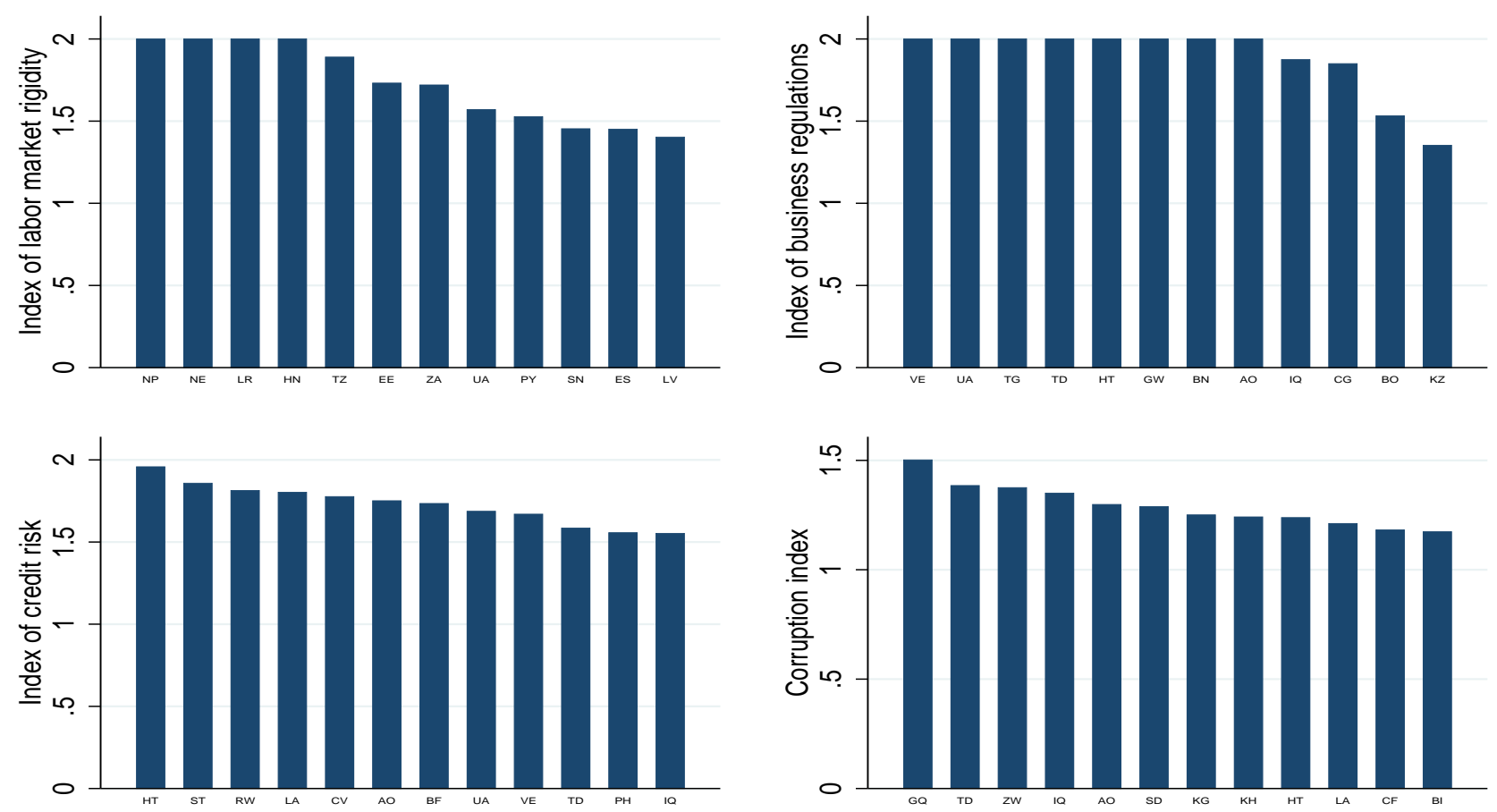

Notes: The index of labor market rigidity is estimated by combining all the labor regulations (limits on fixed term contracts; limits on working days per week; employment protection measures; and the minimum wage) with a principal component analysis. The index of business regulations is estimated by combining all the business regulations (the time it takes to open a business; the time it takes to register property; the time it takes to pay taxes; the time it takes to export goods) with a principal component analysis. The index of credit risk is estimated by combining all the credit regulations (100credit coverage; 10-investor protection; enforcing contracts; 100-resolving insolvency) with a principal component analysis. The corruption index is the inverse of the estimated control of the corruption indicator. 
Figure 6: Extensive margin of offshoring, institutions and network
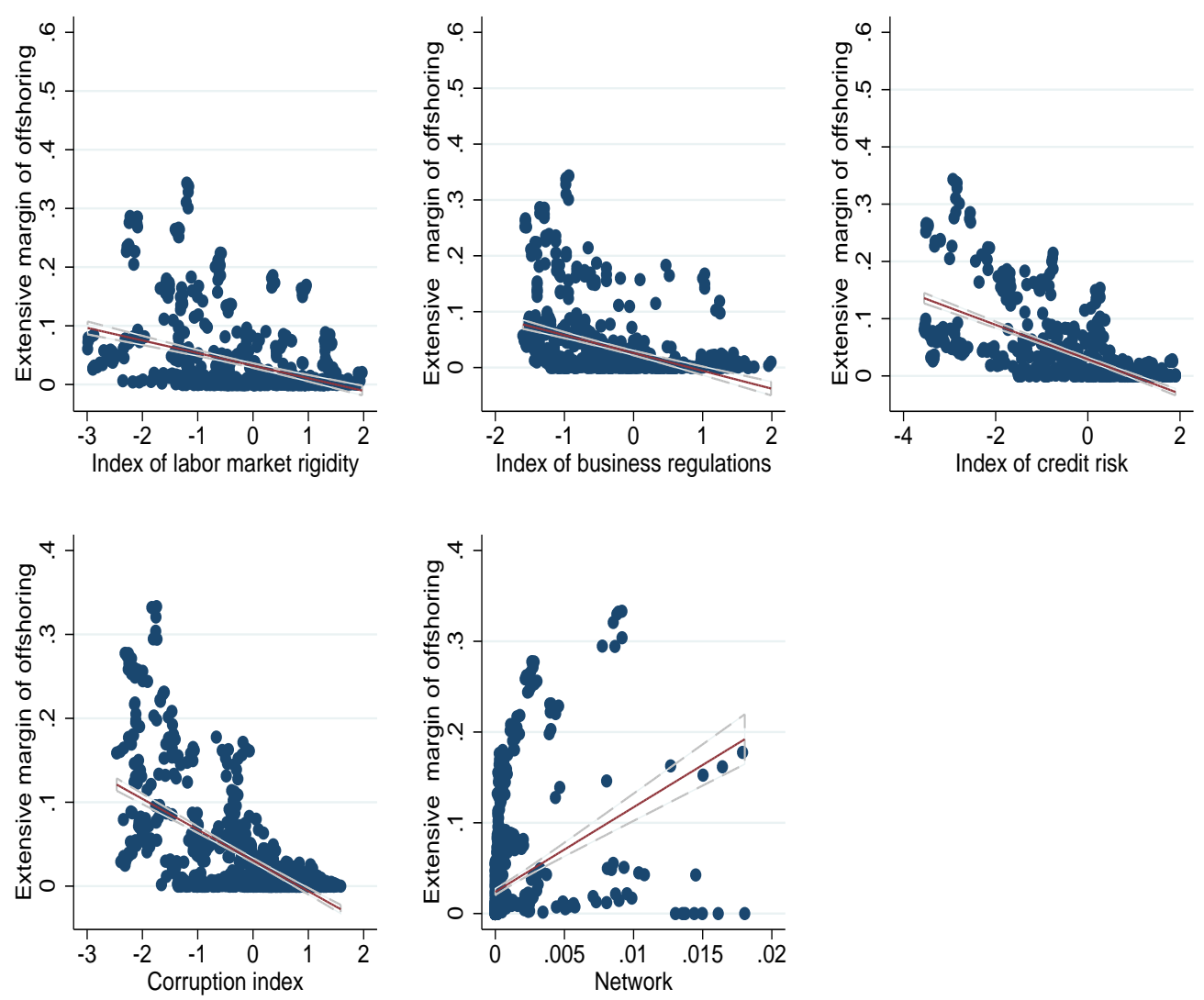

Notes: The share of firms that offshore at the year-destination level are reported on the vertical axis. The index of regulations or the network variable at the year-destination level are reported on the horizontal axis. A network is measured as the firm-level bilateral share of foreign workers. 
Figure 7: Intensive margin of offshoring, institutions and networks
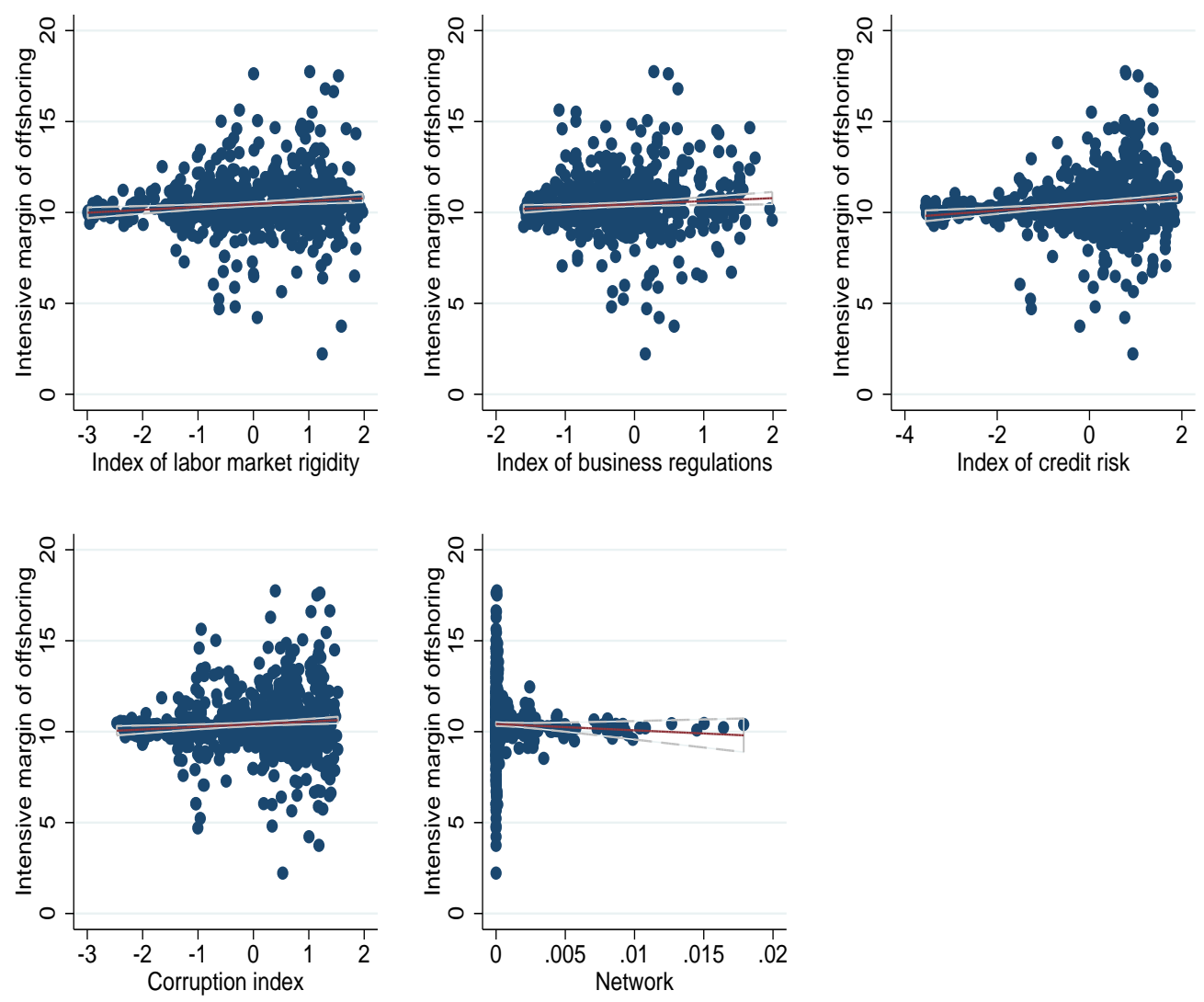

Notes: The average intensive margin of offshoring at the year-destination level is reported on the vertical axis. The index of regulations or the network variable at the year-destination level are reported on the horizontal axis. A network is measured as the firm-level bilateral share of foreign workers. 
Figure 8: Marginal effects of networks on the extensive margin of offshoring
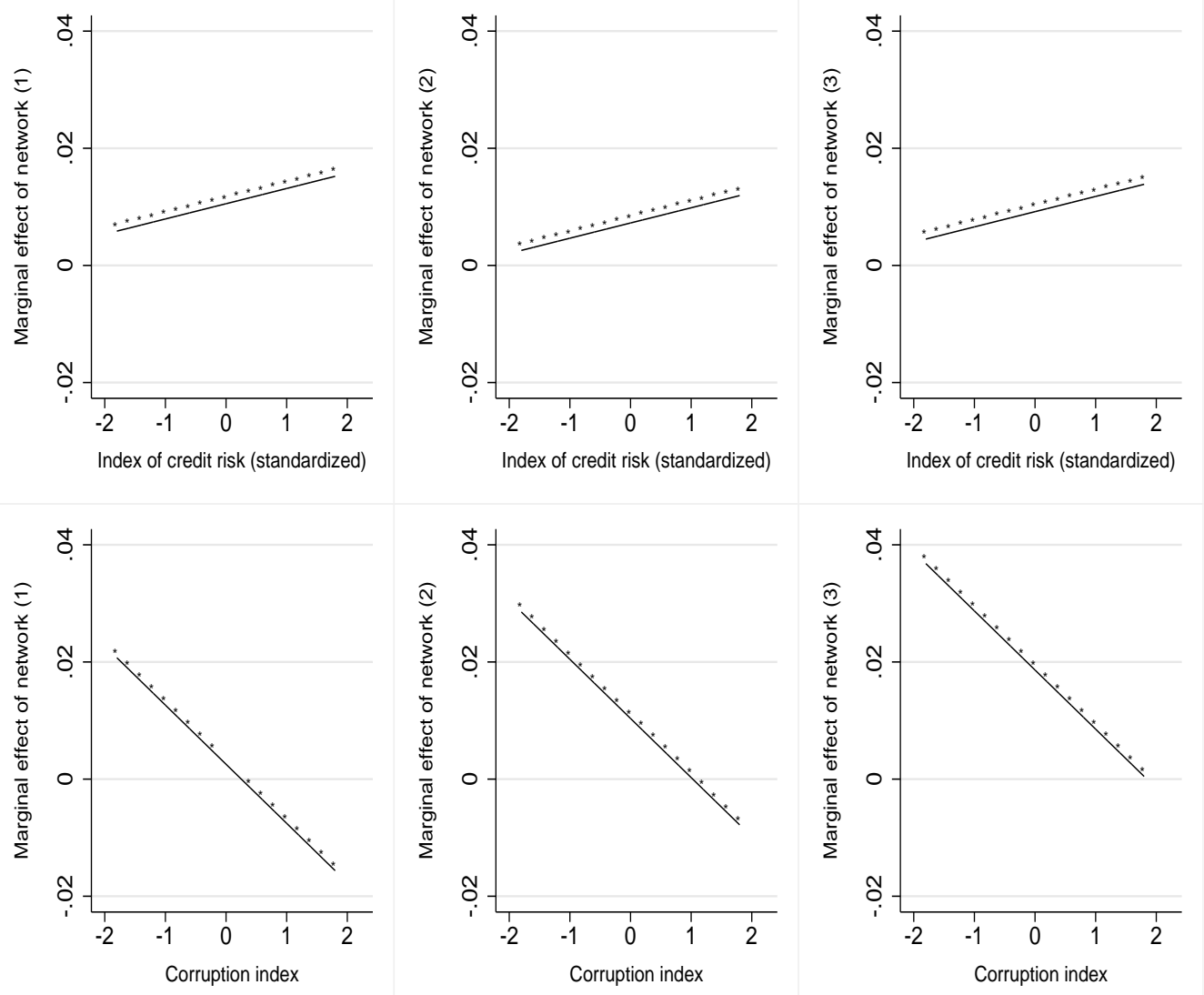

Notes: The marginal effects of networks are estimated from the interaction specification, as reported in column (3) of Table 4. In the top (bottom) panels, the marginal effect of networks (1) is calculated by interacting our network variable with the index of credit risk (corruption) and setting the index of labor market rigidity, business regulation and corruption (credit risk) at the 25th percentile of their distributions. In the top (bottom) panels, the marginal effect of networks (2) is calculated by interacting our network variable with the index of credit risk (corruption) and setting the index of labor market rigidity, business regulation and corruption (credit risk) at the median of their distributions. In the top (bottom) panels, the marginal effect of networks (3) is calculated by interacting our network variable with the index of credit risk (corruption) and setting the index of labor market rigidity, business regulations and corruption (credit risk) at the 75 th percentile of their distributions. "**" indicates significance at the $95 \%$ level. 


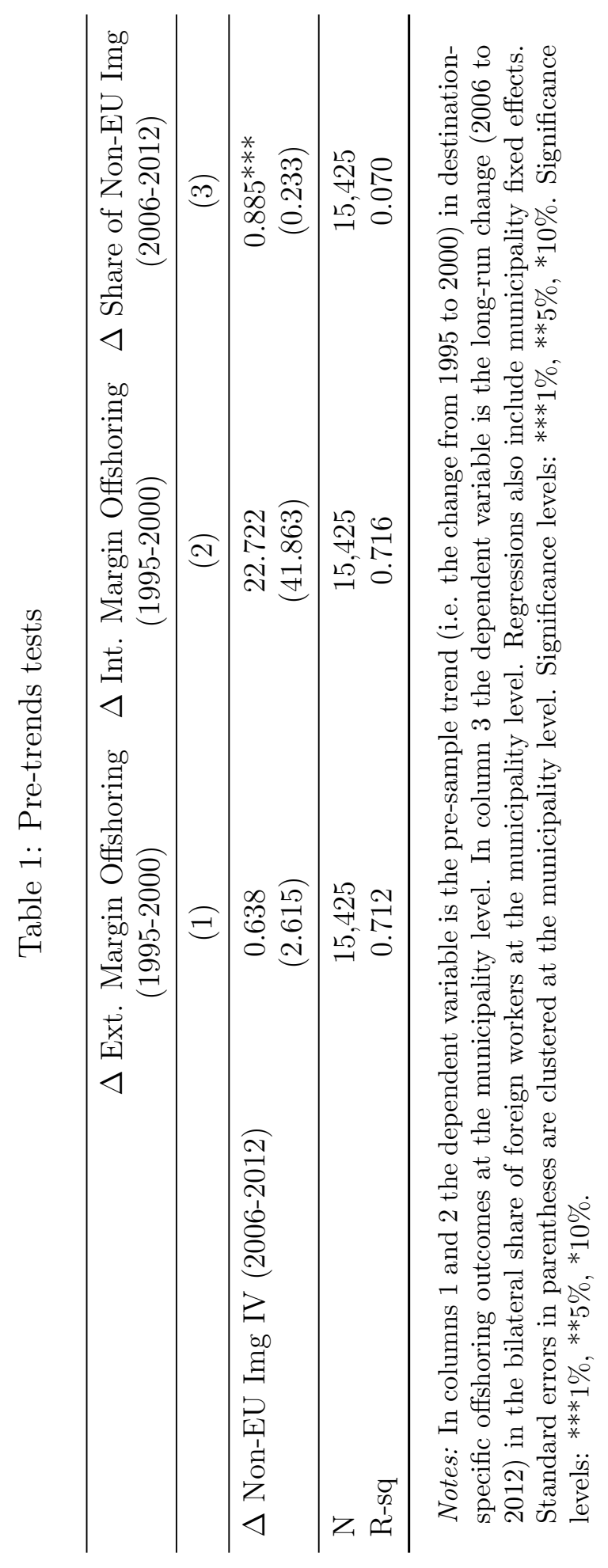




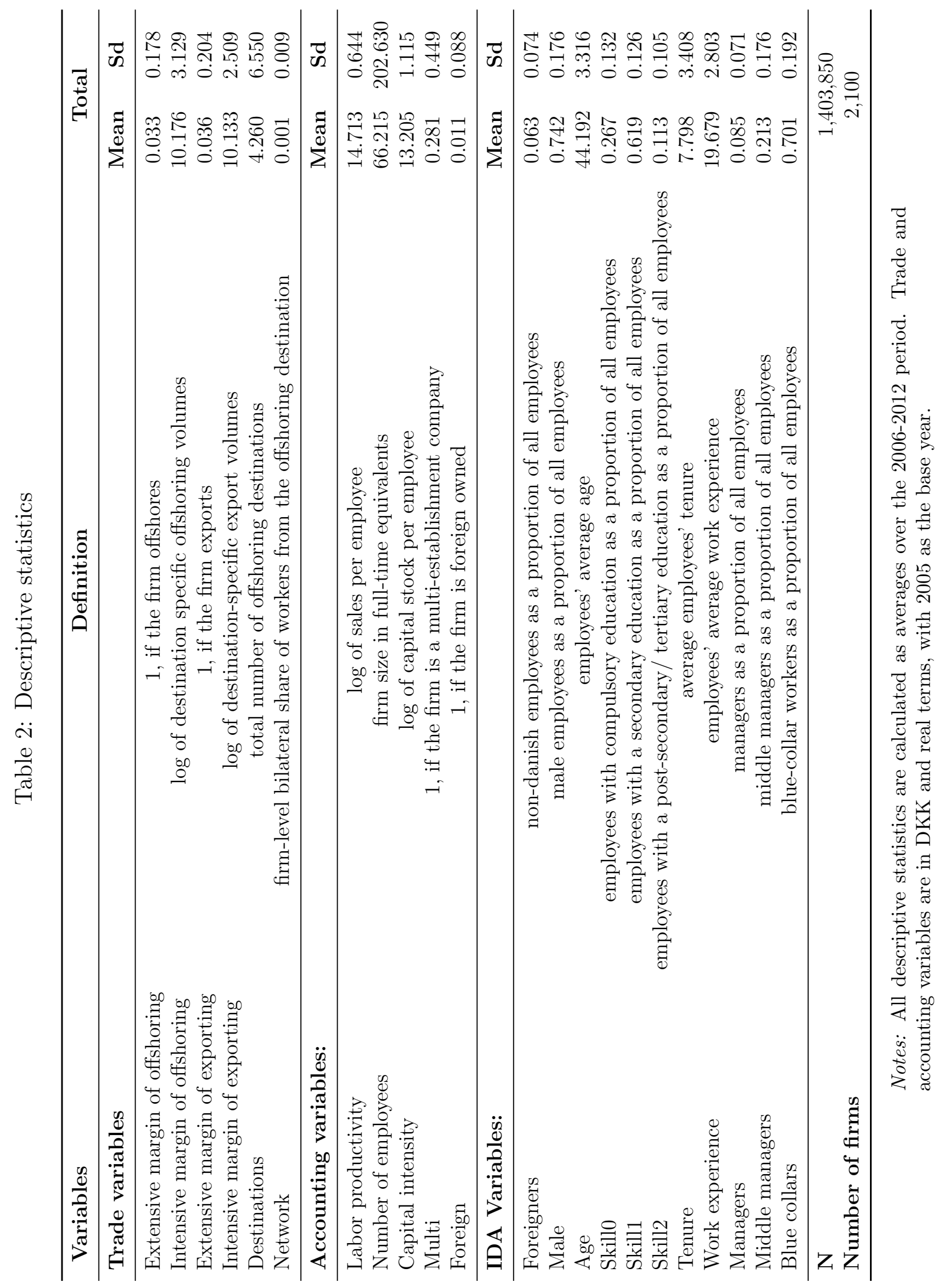


Table 3: Labor, business and credit regulations

\begin{tabular}{lcccc}
\hline & Mean & Sd & Min & Max \\
\hline Labor regulations & & & & \\
Limits on fixed term contracts & 0.388 & 0.487 & 0 & 1 \\
Limits on working days per week & 1.073 & 0.319 & 0 & 2 \\
Employment protection measures & 0.486 & 0.499 & 0 & 1 \\
Minimum wage & 0.305 & 0.251 & 0 & 1.779 \\
Index of labor market rigidity & -0.067 & 1.086 & -2.702 & 2 \\
Business regulations & & & & \\
Time to open a business & 33.083 & 34.976 & 0.500 & 260 \\
Time to register property & 59.878 & 65.847 & 1 & 398 \\
Time to pay taxes & 293.562 & 221.891 & 0 & 2085 \\
Time to export & 23.633 & 16.298 & 6 & 102 \\
Index of business regulations & -0.069 & 1.072 & -1.601 & 2 \\
Credit regulations & & & & \\
100-Credit coverage & 75.952 & 33.664 & 0 & 100 \\
10-Investor protection & 4.985 & 2.463 & 0 & 10 \\
Enforcing contracts & 28.925 & 12.666 & 0.100 & 87.6 \\
100-Resolving insolvency & 64.546 & 23.708 & 8.800 & 100 \\
Index of credit risk & -0.128 & 1.286 & -3.552 & 1.900 \\
Corruption index & 0.018 & 1.013 & -2.385 & 2.465 \\
\hline N & & $1,403,850$ & \\
\hline
\end{tabular}

Notes: Means and standard deviations are calculated as averages over the 2006-2012 period. Labor regulations are the following: i) Whether fixed contracts for permanent tasks are forbidden or not; ii) Maximum number of working days weekly (calculated as 7-maximum number of working days); iii) Notification/consultation with a third party to dismiss redundant workers; iv) Minimum wages, ratio of average wages. The index of labor market rigidity is estimated with a principal component analysis using all labor regulations. Business regulations are the following: i) Time required to start a business (days); ii) Time required to register property (days); iii) Time to prepare and pay taxes (hours); iv) Time to import (days); v) Time to export (days). The index of business regulations is estimated with a principal component analysis by using all business regulations. Credit regulations are the following: i) Lack of credit coverage $=100$-Private credit bureau coverage (percent of adults); ii) Lack of investor protection $=10$-Business extent of disclosure index $(0=$ less disclosure to $10=$ more disclosure); iii) Enforcing contracts, cost (percent of claims); iv) Rate of insolvency $=100$-recovery rate (cents on the dollar). The index of credit risk is estimated with a principal component analysis using all credit regulations. The corruption index is the inverse of the estimated control of corruption indicator. 


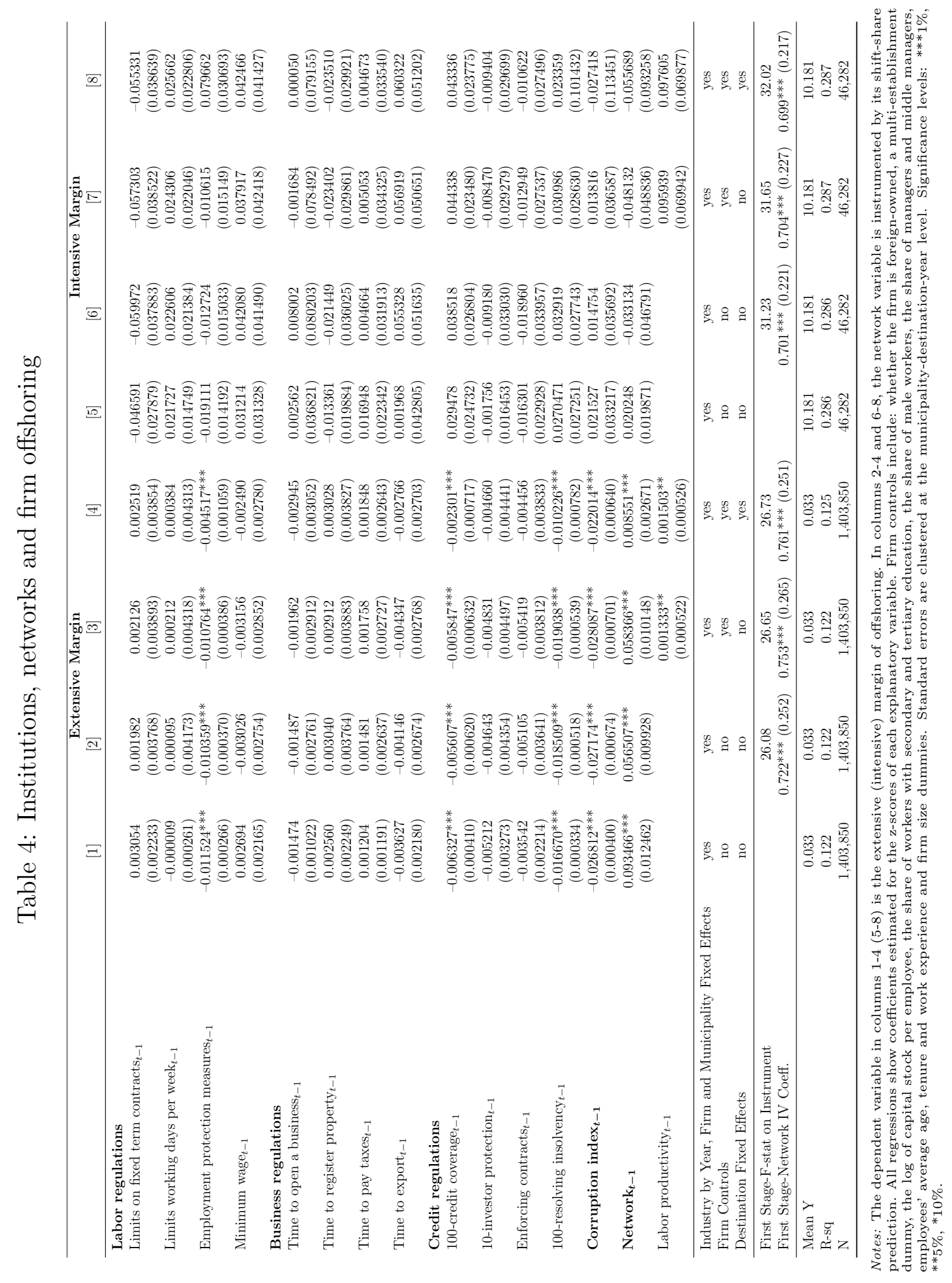




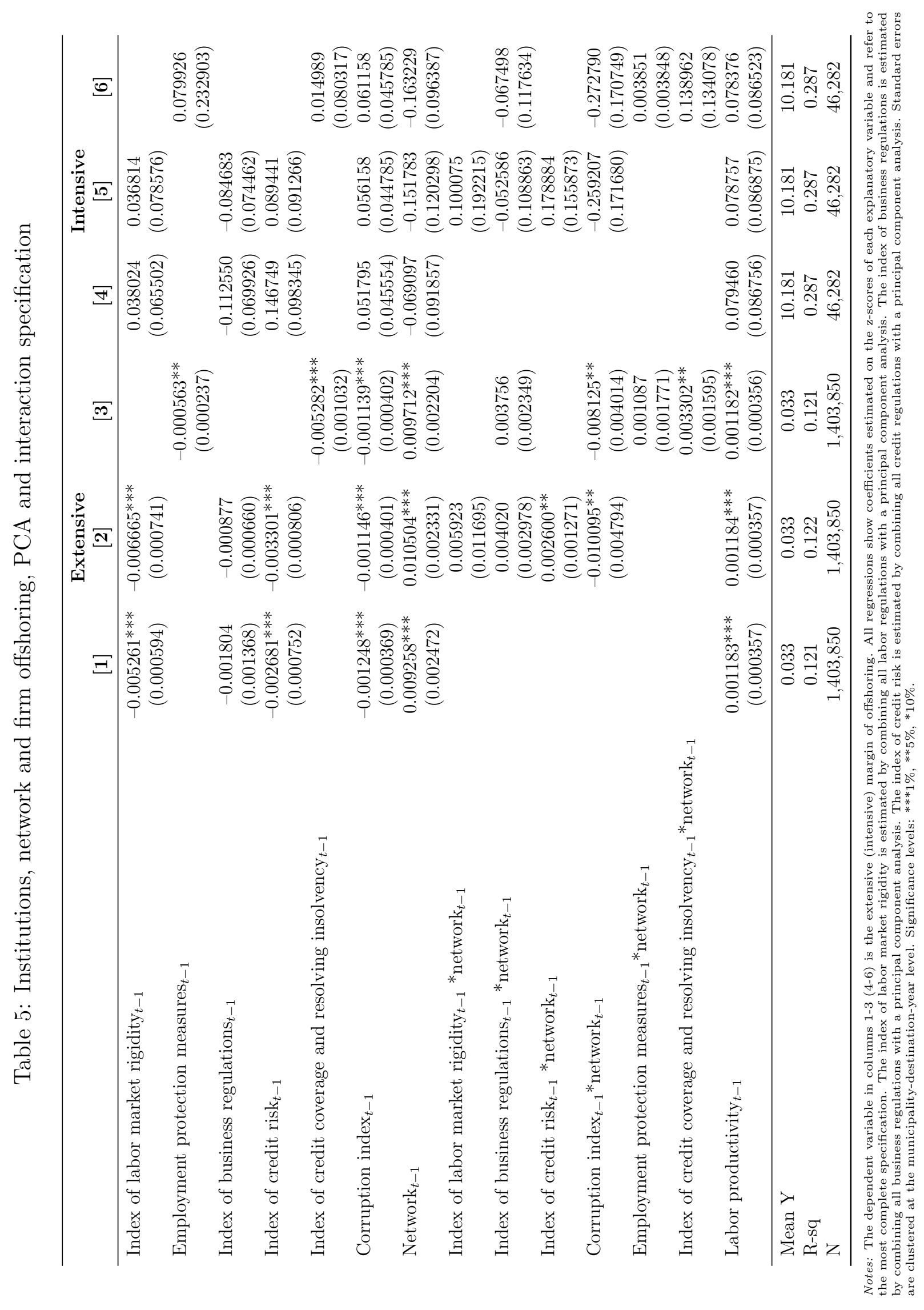




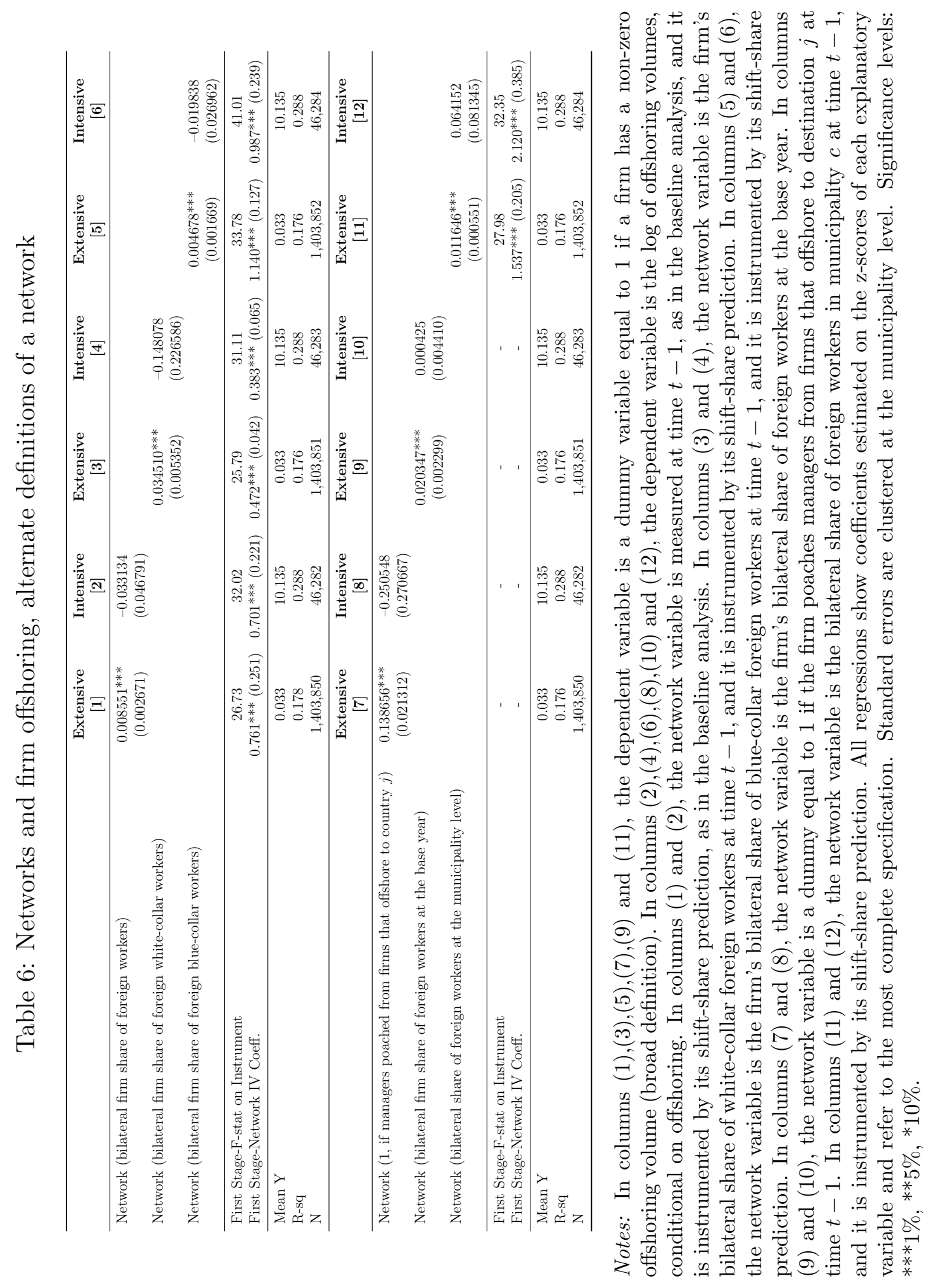


Table 7: Institutions and networks, the role of non-linearities in offshoring decisions and of export outcomes

\begin{tabular}{|c|c|c|c|c|}
\hline & \multicolumn{2}{|c|}{ Offshoring } & \multicolumn{2}{|c|}{ Export } \\
\hline & $\begin{array}{c}\text { Extensive } \\
{[1]}\end{array}$ & $\begin{array}{c}\text { Intensive } \\
{[2]}\end{array}$ & $\begin{array}{c}\text { Extensive } \\
{[1]}\end{array}$ & $\begin{array}{c}\text { Intensive } \\
{[2]}\end{array}$ \\
\hline Index of labor market rigidity ${ }_{t-1}$ & $\begin{array}{c}-0.004756^{* * *} \\
(0.000436)\end{array}$ & $\begin{array}{c}0.004385 \\
(0.099843)\end{array}$ & $\begin{array}{l}-0.024258 \\
(0.021569)\end{array}$ & $\begin{array}{l}-0.338879 \\
(0.252259)\end{array}$ \\
\hline Index of labor market rigidity ${ }_{t-1}^{2}$ & $\begin{array}{c}0.000806^{* * *} \\
(0.000260)\end{array}$ & $\begin{array}{c}0.014632 \\
(0.074298)\end{array}$ & & \\
\hline Index of business regulations $_{t-1}$ & $\begin{array}{l}-0.000215 \\
(0.000552)\end{array}$ & $\begin{array}{l}-0.058580 \\
(0.086191)\end{array}$ & $\begin{array}{c}0.006661 \\
(0.004868)\end{array}$ & $\begin{array}{c}0.074535 \\
(0.045147)\end{array}$ \\
\hline Index of business regulations ${ }_{t-1}^{2}$ & $\begin{array}{c}0.000749 \\
(0.000498)\end{array}$ & $\begin{array}{l}-0.043573 \\
(0.034185)\end{array}$ & & \\
\hline Index of credit risk ${ }_{t-1}$ & $\begin{array}{c}-0.003436^{* * *} \\
(0.000636)\end{array}$ & $\begin{array}{c}0.131934 \\
(0.130959)\end{array}$ & $\begin{array}{c}-0.018241^{* * *} \\
(0.002045)\end{array}$ & $\begin{array}{l}-0.031200 \\
(0.037783)\end{array}$ \\
\hline Index of credit risk ${ }_{t-1}^{2}$ & $\begin{array}{c}0.002544^{* * *} \\
(0.000804)\end{array}$ & $\begin{array}{c}0.002354 \\
(0.062133)\end{array}$ & & \\
\hline Corruption index $x_{t-1}$ & $\begin{array}{l}-0.000062 \\
(0.000547)\end{array}$ & $\begin{array}{l}-0.024040 \\
(0.152086)\end{array}$ & $\begin{array}{c}-0.002204^{* *} \\
(0.000962)\end{array}$ & $\begin{array}{c}-0.111308^{* *} \\
(0.051552)\end{array}$ \\
\hline Corruption index $x_{t-1}^{2}$ & $\begin{array}{c}-0.002557^{* * *} \\
(0.000869)\end{array}$ & $\begin{array}{c}0.038669 \\
(0.062198)\end{array}$ & & \\
\hline Network $_{t-1}$ & $\begin{array}{c}0.019900^{* * *} \\
(0.002451)\end{array}$ & $\begin{array}{c}0.123127 \\
(0.165955)\end{array}$ & $\begin{array}{c}0.027574^{* * * *} \\
(0.006645)\end{array}$ & $\begin{array}{c}0.111999 \\
(0.082117)\end{array}$ \\
\hline Network $_{t-1}^{2}$ & $\begin{array}{c}-0.002412^{* * *} \\
(0.000345)\end{array}$ & $\begin{array}{l}-0.050437 \\
(0.030761)\end{array}$ & & \\
\hline Mean Y & 0.033 & 10.181 & 0.036 & 10.133 \\
\hline R-sq & 0.179 & 0.291 & 0.385 & 0.391 \\
\hline $\mathrm{N}$ & $1,403,850$ & 46,282 & $1,403,850$ & 144,701 \\
\hline
\end{tabular}

Notes: The dependent variable in column 1 (2) is the extensive (intensive) margin of offshoring. Dependent variable in column 3 (4) is the extensive (intensive) margin of exporting. All regressions show coefficients estimated on the z-scores of each explanatory variable and refer to the most complete specification. Standard errors are clustered at the municipality-destination-year level. Significance levels: $* * * 1 \%, * * 5 \%, * 10 \%$. 


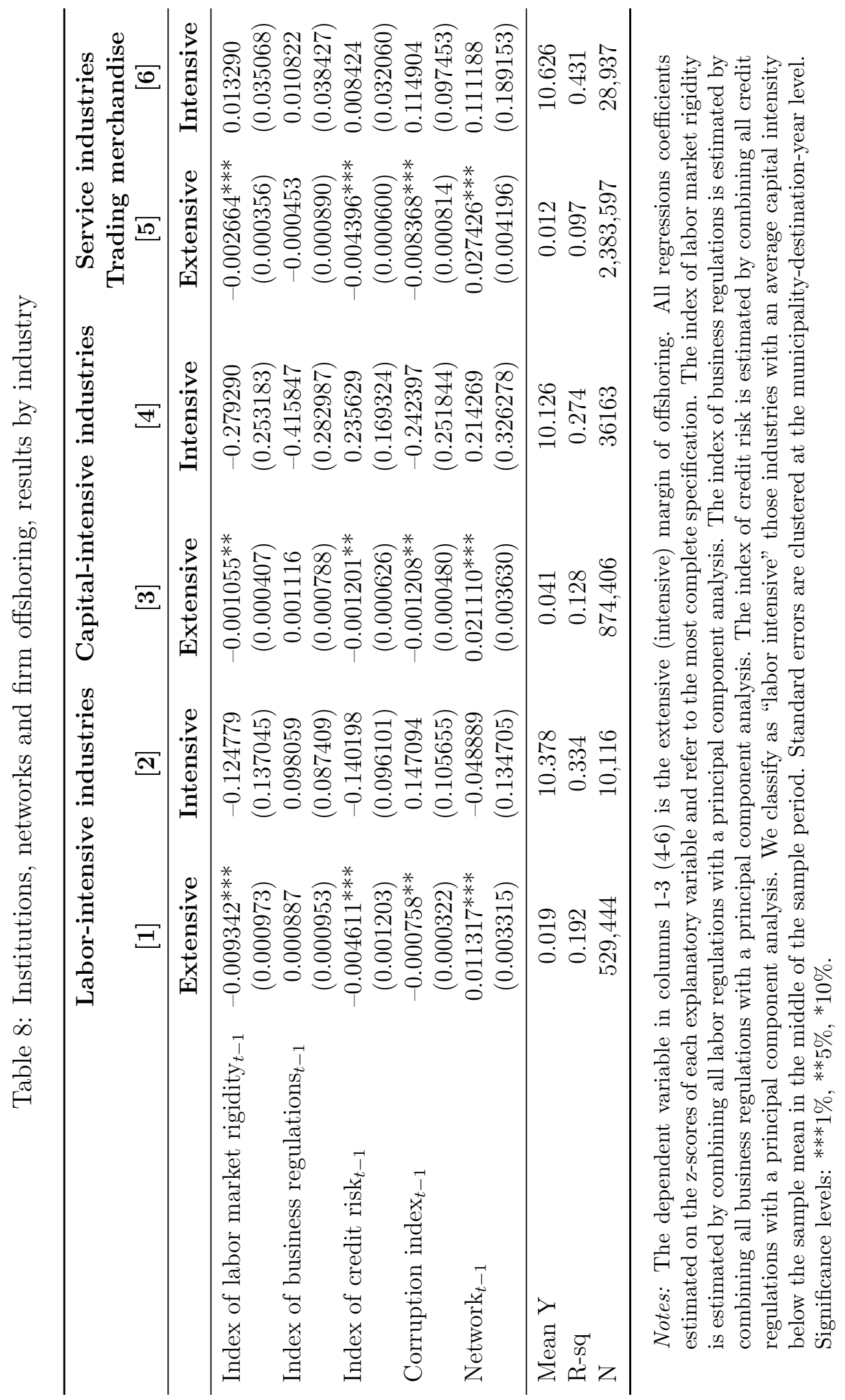




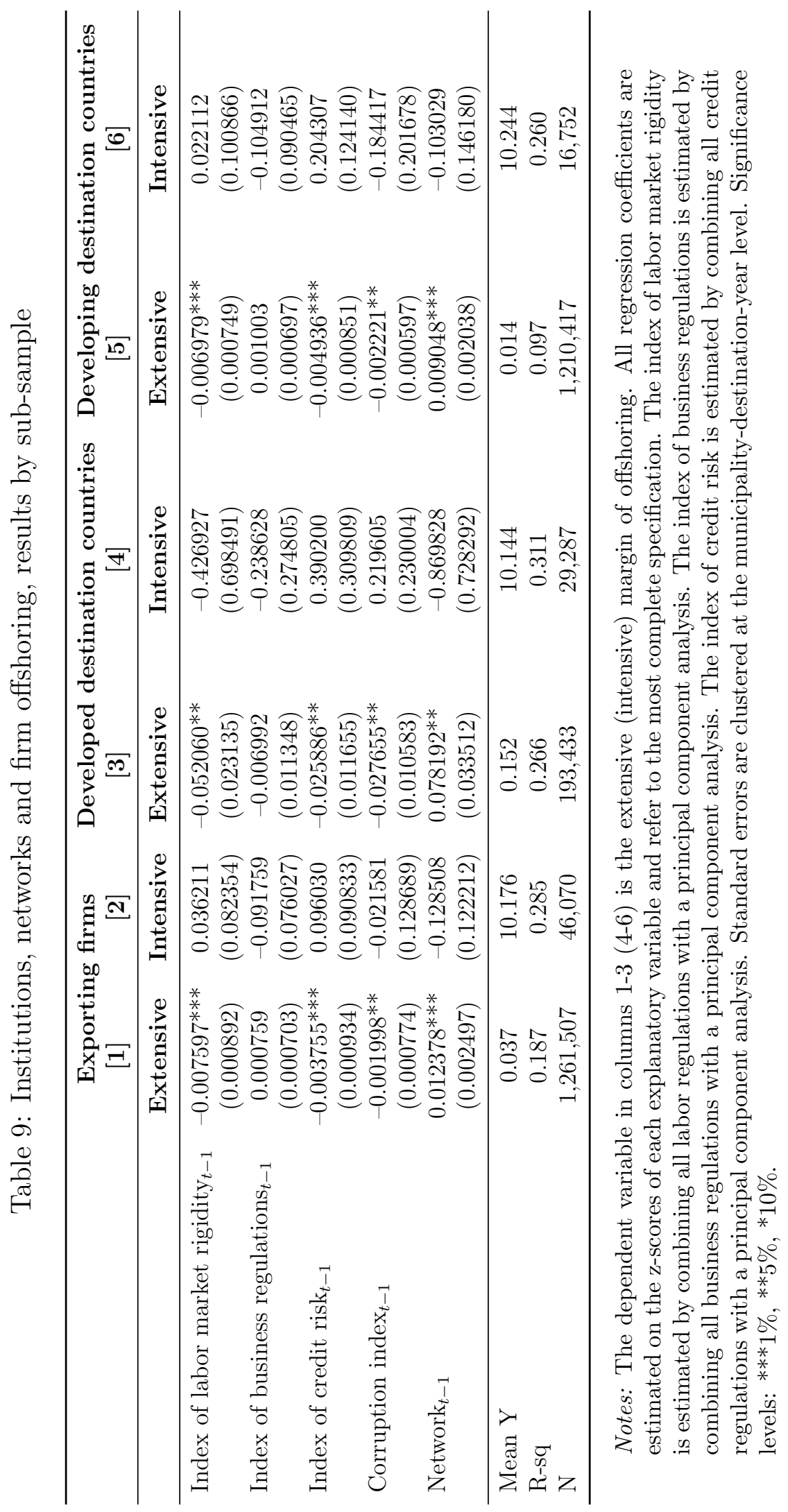




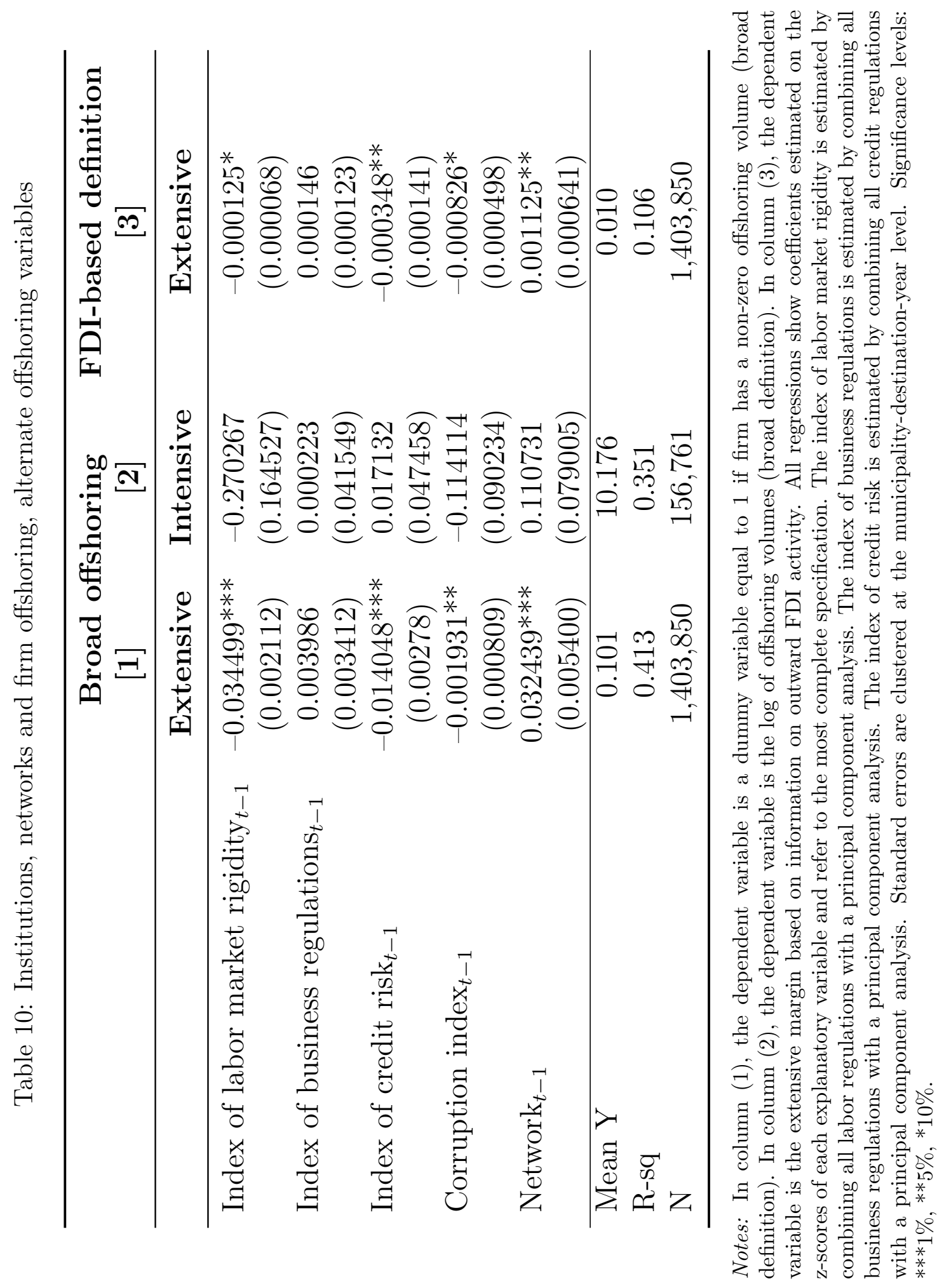

